4

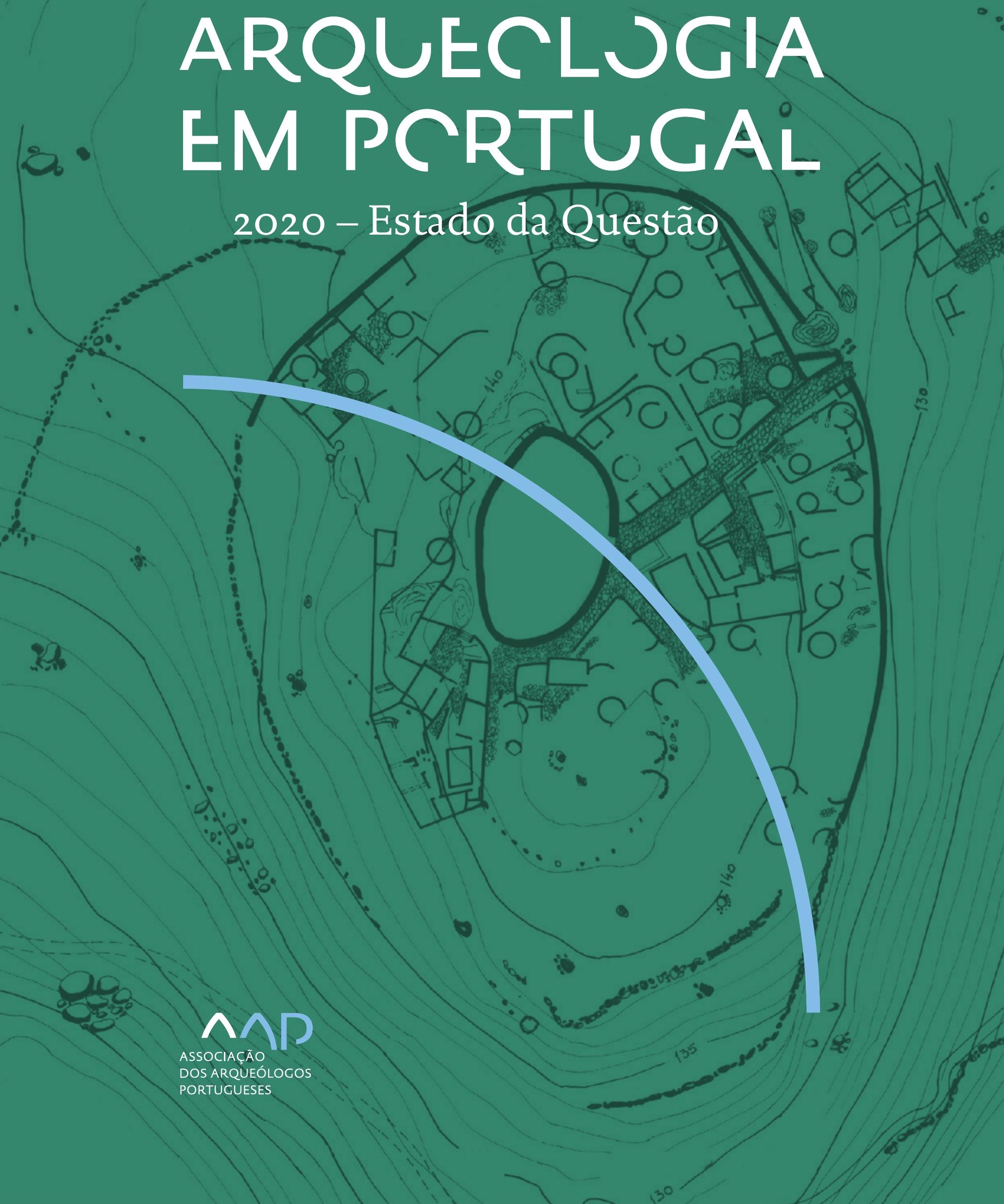


Coordenação editorial: José Morais Arnaud, César Neves e Andrea Martins Design gráfico: Flatland Design

AAP - ISBN: 978-972-9451-89-8

CITCEM - ISBN: 978-989-8970-25-1

Associação dos Arqueólogos Portugueses e CITCEM

Lisboa, 2020

O conteúdo dos artigos é da inteira responsabilidade dos autores. Sendo assim a Associação dos Arqueólogos Portugueses declina qualquer responsabilidade por eventuais equívocos ou questões de ordem ética e legal.

Desenho de capa:

Planta do castro de Monte Mozinho (Museu Municipal de Penafiel).

\section{$\hat{\wedge} \mathrm{P}$}

DOS ARQUEÓLOGOS PORTUGUESES

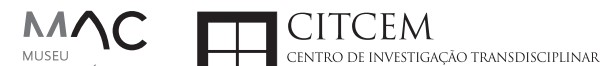
MUSEU
ARQUELLÓGICO
DO CARMO
U.PORTO

FLUP FACULDADE DE LETRAS
UNIVERSIDADE DO PORTO

Apoio

EC para a Ciência 


\section{Índice}

15 Prefácio

José Morais Arnaud

\section{Historiografia e Teoria}

17 Território, comunidade, memória e emoção: a contribuição da história da arqueologia (algumas primeiras e breves reflexões)

Ana Cristina Martins

25 Como descolonizar a arqueologia portuguesa?

Rui Gomes Coelho

41 Arqueologia e Modernidade: uma revisitação pessoal e breve de alguns aspetos da obra homónima de Julian Thomas de 2004

Vítor Oliveira Jorge

57 Dados para a História das Mulheres na Arqueologia portuguesa, dos finais do século XIX aos inícios do século XX: números, nomes e tabelas

Filipa Dimas / Mariana Diniz

73 Retractos da arqueologia portuguesa na imprensa: (in)visibilidades no feminino

Catarina Costeira / Elsa Luís

85 Arqueologia e Arqueólogos no Norte de Portugal Jacinta Bugalhão

101 Vieira Guimarães (1864-1939) e a arqueologia em Tomar: uma abordagem sobre o território e as gentes

João Amendoeira Peixoto / Ana Cristina Martins

115 Os memoráveis? A arqueologia algarvia na imprensa nacional e regional na presente centúria (2001-2019): características, visões do(s) passado(s) e a arqueologia

enquanto marca

Frederico Agosto / João Silva

129 A Evolução da Arqueologia Urbana e a Valorização Patrimonial no Barlavento Algarvio: Os casos de Portimão e Silves

Artur Mateus / Diogo Varandas / Rafael Boavida

\section{Gestão, Valorização e Salvaguarda do Património}

145 O Caderno Reivindicativo e as condições de trabalho em Arqueologia Miguel Rocha / Liliana Matias Carvalho / Regis Barbosa / Mauro Correia / Sara Simões / Jacinta Bugalhão / Sara Brito / Liliana Veríssimo Carvalho / Richard Peace / Pedro Peça / Cézer Santos

155 Os Estudos de Impacte Patrimonial como elemento para uma estratégia sustentável de minimização de impactes no âmbito de reconversões agrícolas Tiago do Pereiro

165 Salvaguarda de Património arqueológico em operações florestais: gestão e sensibilização Filipa Bragança / Gertrudes Zambujo / Sandra Lourenço / Belém Paiva / Carlos Banha / Frederico Tatá Regala / Helena Moura / Jacinta Bugalhão / João Marques / José Correia / Pedro Faria / Samuel Melro

179 Os valores do Património: uma investigação sobre os Sítios Pré-históricos de Arte Rupestre do Vale do Rio Côa e de Siega Verde José Paulo Francisco 
189 Conjugando recursos arqueológicos e naturais para potenciar as visitas ao Geoparque Litoral de Viana do Castelo (Noroeste de Portugal)

Hugo A. Sampaio / Ana M.S. Bettencourt / Susana Marinho / Ricardo Carvalhido

203 Áreas de Potencial Arqueológico na Região do Médio Tejo: Modelo Espacial Preditivo Rita Ferreira Anastácio / Ana Filipa Martins / Luiz Oosterbeek

223 Património Arqueológico e Gestão Territorial: O contributo da Arqueologia para a revisão do PDM de Avis

Ana Cristina Ribeiro

237 A coleção arqueológica do extinto Museu Municipal do Porto - Origens, Percursos e Estudos

Sónia Couto

251 Valpaços - uma nova carta arqueológica

Pedro Pereira / Maria de Fátima Casares Machado

263 Arqueologia na Cidade de Peniche

Adriano Constantino / Luís Rendeiro

273 Arqueologia Urbana: a cidade de Lagos como caso de Estudo Cátia Neto

285 Estratégias de promoção do património cultural subaquático nos Açores. O caso da ilha do Faial

José Luís Neto / José Bettencourt / Luís Borges / Pedro Parreira

297 Carta Arqueológica da Cidade Velha: Uma primeira abordagem

Jaylson Monteiro / Nireide Tavares / Sara da Veiga / Claudino Ramos / Edson Brito /

Carlos Carvalho / Francisco Moreira / Adalberto Tavares

311 Antropologia Virtual: novas metodologias para a análise morfológica e funcional Ricardo Miguel Godinho / Célia Gonçalves

\section{Didáctica da Arqueologia}

327 Como os projetos de Arqueologia podem contribuir para uma comunidade culturalmente mais consciente Alexandra Figueiredo / Claúdio Monteiro / Adolfo Silveira / Ricardo Lopes

337 Educação Patrimonial - Um cidadão esclarecido é um cidadão ativo! Ana Paula Almeida

351 A aproximação da Arqueologia à sala de aula: um caso de estudo no $3^{\circ}$ ciclo do Ensino Básico Luís Serrão Gil

363 Arqueologia 3.o - Pensar e comunicar a Arqueologia para um futuro sustentável Mónica Rolo

377 “Conversa de Arqueólogos" - Divulgar a Arqueologia em tempos de Pandemia Diogo Teixeira Dias

389 Escola Profissional de Arqueologia: desafios e oportunidades Susana Nunes / Dulcineia Pinto / Júlia Silva / Ana Mascarenhas

399 Os Museus de Arqueologia e os Jovens: a oferta educativa para o público adolescente Beatriz Correia Barata / Leonor Medeiros

411 O museu universitário como mediador entre a ciência e a sociedade: o exemplo da secção de arqueologia no Museu de História Natural e da Ciência da Universidade do Porto (MHNC-UP)

Rita Gaspar 
421 Museu de Lanifícios: Real Fábrica de Panos. Atividades no âmbito da Arqueologia Beatriz Correia Barata / Rita Salvado

427 Arqueologia Pública e o caso da localidade da Mata (Torres Novas) Cláudia Manso / Ana Rita Ferreira / Cristiana Ferreira / Vanessa Cardoso Antunes

431 Do sítio arqueológico ao museu: um percurso (também) didático Lídia Fernandes

447 Estão todos convidados para a Festa! E para dançar também... O projecto do Serviço Educativo do Museu Arqueológico do Carmo na $5^{\underline{a}}$ Edição da Festa da Arqueologia Rita Pires dos Santos

459 O “Clã de Carenque”, um projeto didático de arqueologia Eduardo Gonzalez Rocha

469 Mediação cultural: peixe que puxa carroça nas Ruínas Romanas de Troia Inês Vaz Pinto / Ana Patrícia Magalhães / Patrícia Brum / Filipa Santos

481 Didática Arqueológica, experiências do Projeto Mértola Vila Museu Maria de Fátima Palma / Clara Rodrigues / Susana Gómez / Lígia Rafael

\section{Arte Rupestre}

497 Os inventários de arte rupestre em Portugal Mila Simões de Abreu

513 O projeto FIRST-ART - conservação, documentação e gestão das primeiras manifestações de arte rupestre no Sudoeste da Península Ibérica: as grutas do Escoural e Maltravieso Sara Garcês / Hipólito Collado / José Julio García Arranz / Luiz Oosterbeek / António Carlos Silva / Pierluigi Rosina / Hugo Gomes / Anabela Borralheiro Pereira / George Nash / Esmeralda Gomes / Nelson Almeida / Carlos Carpetudo

523 Trabalhos de documentação de arte paleolítica realizados no âmbito do projeto PalæoCôa André Tomás Santos / António Fernando Barbosa / Luís Luís / Marcelo Silvestre / Thierry Aubry

537 Imagens fantasmagóricas, silhuetas elusivas: as figuras humanas na arte do Paleolítico Superior da região do Côa Mário Reis

$55^{1}$ Os motivos zoomórficos representados nas placas de tear de Vila Nova de São Pedro (Azambuja, Portugal) Andrea Martins / César Neves / José M. Arnaud / Mariana Diniz

571 Arte Rupestre do Monte de Góios (Lanhelas, Caminha). Síntese dos resultados dos trabalhos efectuados em 2007-2009 Mário Varela Gomes

599 Gravuras rupestres de barquiformes no Monte de S. Romão, Guimarães, Noroeste de Portugal Daniela Cardoso

613 Círculos segmentados gravados na Bacia do Rio Lima (Noroeste de Portugal): contributos para o seu estudo Diogo Marinho / Ana M.S. Bettencourt / Hugo Aluai Sampaio

631 Equídeos gravados no curso inferior do Rio Mouro, Monção (NW Portugal). Análise preliminar Coutinho, L.M. / Bettencourt, A.M.S / Sampaio, Hugo A.S

645 Paletas na Arte Rupestre do Noroeste de Portugal. Inventário preliminar Bruna Sousa Afonso / Ana M. S. Bettencourt / Hugo A. Sampaio 


\section{Pré-História}

661 O projeto Miño/Minho: balanço de quatro anos de trabalhos arqueológicos Sérgio Monteiro-Rodrigues / João Pedro Cunha-Ribeiro / Eduardo Méndez-Quintas / Carlos Ferreira / Pedro Xavier / José Meireles / Alberto Gomes / Manuel Santonja / Alfredo Pérez-González

677 A ocupação paleolítica da margem esquerda do Baixo Minho: a indústria lítica do sítio de Pedreiras 2 (Monção, Portugal) e a sua integração no contexto regional Carlos Ferreira / João Pedro Cunha-Ribeiro / Sérgio Monteiro-Rodrigues / Eduardo Méndez-Quintas / Pedro Xavier / José Meireles / Alberto Gomes / Manuel Santonja / Alfredo Pérez-González

693 O sítio acheulense do Plistocénico médio da Gruta da Aroeira Joan Daura / Montserrat Sanz / Filipa Rodrigues / Pedro Souto / João Zilhão

703 As sociedades neandertais no Barlavento algarvio: modelos preditivos com recurso aos SIG

Daniela Maio

715 A utilização de quartzo durante o Paleolítico Superior no território dos vales dos rios Vouga e Côa

Cristina Gameiro / Thierry Aubry / Bárbara Costa / Sérgio Gomes / Luís Luís / Carmen Manzano / André Tomás Santos

733 Uma perspetiva diacrónica da ocupação do concheiro do Cabeço da Amoreira (Muge, Portugal) a partir da tecnologia lítica Joana Belmiro / João Cascalheira / Célia Gonçalves

745 Novos dados sobre a Pré-história Antiga no concelho de Palmela. A intervenção arqueológica no sítio do Poceirão I

Michelle Teixeira Santos

757 Problemas em torno de Datas Absolutas Pré-Históricas no Norte do Alentejo Jorge de Oliveira

771 Povoamento pré-histórico nas áreas montanhosas do NO de Portugal: o Abrigo 1 de Vale de Cerdeira Pedro Xavier / José Meireles / Carlos Alves

783 Apreciação do povoamento do Neolítico Inicial na Baixa Bacia do Douro. A Lavra I (Serra da Aboboreira) como caso de estudo Maria de Jesus Sanches

797 O Processo de Neolitização na Plataforma do Mondego: os dados do Sector C do Outeiro dos Castelos de Beijós (Carregal do Sal)

João Carlos de Senna-Martinez / José Manuel Quintã Ventura / Andreia Carvalho / Cíntia Maurício

823 Novos trabalhos na Lapa da Bugalheira (Almonda, Torres Novas) Filipa Rodrigues / Pedro Souto / Artur Ferreira / Alexandre Varanda / Luís Gomes / Helena Gomes / João Zilhão

837 A pedra polida e afeiçoada do sítio do Neolítico médio da Moita do Ourives (Benavente, Portugal)

César Neves

857 Casal do Outeiro (Encarnação, Mafra): novos contributos para o conhecimento do povoamento do Neolítico final na Península de Lisboa.

Cátia Delicado / Carlos Maneira e Costa / Marta Miranda / Ana Catarina Sousa

873 Stresse infantil, morbilidade e mortalidade no sítio arqueológico do Neolítico Final/ Calcolítico ( $4^{\circ}$ e $3^{\circ}$ milénio a.C.) do Monte do Carrascal 2 (Ferreira do Alentejo, Beja) Liliana Matias de Carvalho / Sofia N. Wasterlain 
885 Come together: O Conjunto Megalítico das Motas (Monção, Viana do Castelo) e as expressões Campaniformes do Alto Minho Ana Catarina Basílio / Rui Ramos

899 Trabalhos arqueológicos no sítio Calcolítico da Pedreira do Poio Carla Magalhães / João Muralha / Mário Reis / António Batarda Fernandes

913 O sítio arqueológico de Castanheiro do Vento. Da arquitectura do sítio à arquitectura de um território João Muralha Cardoso

925 Estudo zooarqueológico das faunas do Calcolítico final de Vila Nova de São Pedro (Azambuja, Portugal): Campanhas de 2017 e 2018 Cleia Detry / Ana Catarina Francisco / Mariana Diniz / Andrea Martins / César Neves / José Morais Arnaud

943 As faunas depositadas no Museu Arqueológico do Carmo provenientes de Vila Nova de São Pedro (Azambuja): as campanhas de 1937 a 1967 Ana Catarina Francisco / Cleia Detry / César Neves / Andrea Martins / Mariana Diniz / José Morais Arnaud

959 Análise funcional de material lítico em sílex do castro de Vila Nova de S. Pedro (Azambuja, Portugal): uma primeira abordagem Rafael Lima

971 O recinto da Folha do Ouro 1 (Serpa) no contexto dos recintos de fossos calcolíticos alentejanos

António Carlos Valera / Tiago do Pereiro / Pedro Valério / António M. Monge Soares

\section{Proto-História}

987 Produção de sal marinho na Idade do Bronze do noroeste Português. Alguns dados para uma reflexão

Ana M. S. Bettencourt / Sara Luz / Nuno Oliveira / Pedro P. Simões / Maria Isabel C. Alves / Emílio Abad-Vidal

1001 A estátua-menir do Pedrão ou de São Bartolomeu do Mar (Esposende, noroeste de Portugal) no contexto arqueológico da fachada costeira de entre os rios Neiva e Cávado Ana M. S. Bettencourt / Manuel Santos-Estévez / Pedro Pimenta Simões / Luís Gonçalves

1015 O Castro do Muro (Vandoma/Baltar, Paredes) - notas para uma biografia de ocupação da Idade do Bronze à Idade Média

Maria Antónia D. Silva / Ana M. S. Bettencourt / António Manuel S. P. Silva / Natália Félix

1031 Do Bronze Final à Idade Média - continuidades e hiatos na ocupação de Povoados em Oliveira de Azeméis João Tiago Tavares / Adriaan de Man

1041 As faunas do final da Idade do Bronze no Sul de Portugal: leituras desde o Outeiro do Circo (Beja)

Nelson J. Almeida / Íris Dias / Cleia Detry / Eduardo Porfírio / Miguel Serra

1055 A Espada do Monte das Oliveiras (Serpa) - uma arma do Bronze Pleno do Sudoeste Rui M. G. Monge Soares / Pedro Valério / Mariana Nabais / António M. Monge Soares

1065 São Julião da Branca (Albergaria-a-Velha) - Investigação e valorização de um povoado do Bronze Final

António Manuel S. P. Silva / Paulo A. P. Lemos / Sara Almeida e Silva / Edite Martins de Sá

1083 Do castro de S. João ao Mosteiro de Santa Clara: notícia de uma intervenção arqueológica, em Vila do Conde Rui Pinheiro 
1095 O castro de Ovil (Espinho), um quarto de século de investigação - resultados e questões em aberto

Jorge Fernando Salvador / António Manuel S. P. Silva

1111 O Castro de Salreu (Estarreja), um povoado proto-histórico no litoral do Entre Douro e Vouga

Sara Almeida e Silva / António Manuel S. P. Silva / Paulo A. P. Lemos / Edite Martins de Sá

1127 Castro de Nossa Senhora das Necessidades (Sernancelhe): uma primeira análise artefactual Telma Susana O. Ribeiro

${ }_{1141}$ A cividade de Bagunte. O estado atual da investigação Pedro Brochado de Almeida

1153 Zoomorfos na cerâmica da Idade do Ferro no NW Peninsular: inventário, cronologias e significado Nuno Oliveira / Cristina Seoane

1163 Vasos gregos em Portugal: diferentes maneiras de contar a história do intercâmbio cultural na Idade do Ferro

Daniela Ferreira

1175 Os exotica da necrópole da Idade do Ferro do Olival do Senhor dos Mártires (Alcácer do Sal) no seu contexto regional

Francisco B. Gomes

\section{Antiguidade Clássica e Tardia}

1191 O uso de madeira como combustível no sítio da Quinta de Crestelos (Baixo Sabor): da Idade do Ferro à Romanização Filipe Vaz / João Tereso / Sérgio Simões Pereira / José Sastre / Javier Larrazabal Galarza / Susana Cosme / José António Pereira / Israel Espi

1207 Cultivos de Época Romana no Baixo Sabor: continuidade em tempos de mudança? João Pedro Tereso / Sérgio Simões Pereira / Filipe Santos / Luís Seabra / Filipe Vaz

1221 A casa romana na Hispânia: aplicação dos modelos itálicos nas províncias ibéricas Fernanda Magalhães / Diego Machado / Manuela Martins

1235 As pinturas murais romanas da Rua General Sousa Machado, n. ${ }^{5}$ 1, Chaves José Carvalho

1243 Trás do Castelo (Vale de Mir, Pegarinhos, Alijó) - Uma exploração agrícola romana do Douro

Tony Silvino / Pedro Pereira

1255 A sequência de ocupação no quadrante sudeste de Bracara Augusta: as transformações de uma unidade doméstica Lara Fernandes / Manuela Martins

1263 Os Mosaicos com decoração geométrica e geométrico-vegetalista dos sítios arqueológicos da área do Conuentus Bracaraugustanus. Novas abordagens quanto à conservação, restauro, decoração e datação Maria de Fátima Abraços / Licínia Wrench

1277 “Casa Romana” do Castro de São Domingos (Cristelos, Lousada): Escavação, Estudo e Musealização Paulo André de P. Lemos

1291 A arqueobotânica no Castro de Guifões (Matosinhos, Noroeste de Portugal): O primeiro estudo carpológico

Luís Seabra / Andreia Arezes / Catarina Magalhães / José Varela / João Pedro Tereso 
1305 Um Horreum Augustano na Foz do Douro (Monte do Castelo de Gaia, Vila Nova de Gaia) Rui Ramos

1311 Ponderais romanos na Lusitânia: padrões, formas, materiais e contextos de utilização Diego Barrios Rodríguez

1323 Um almofariz centro-itálico na foz do Mondego

Marco Penajoia

1335 Estruturas romanas de Carnide - Lisboa Luísa Batalha / Mário Monteiro / Guilherme Cardoso

1347 O contexto funerário do sector da "necrópole NO" da Rua das Portas de S. Antão (Lisboa): o espaço, os artefactos, os indivíduos e a sua interconectividade na interpretação do passado Sílvia Loja, José Carlos Quaresma, Nelson Cabaço, Marina Lourenço, Sílvia Casimiro, Rodrigo Banha da Silva, Francisca Alves-Cardoso

${ }_{1361}$ Povoamento em época Romana na Amadora - resultados de um projeto pluridisciplinar Gisela Encarnação / Vanessa Dias

1371 A Arquitectura Residencial em Mirobriga (Santiago do Cacém): contributo a partir de um estudo de caso Filipe Sousa / Catarina Felício

${ }_{1385}$ O fim do ciclo. Saneamento e gestão de resíduos nos edifícios termais de Mirobriga (Santiago do Cacém)

Catarina Felício / Filipe Sousa

1399 Balsa, Topografia e Urbanismo de uma Cidade Portuária Vítor Silva Dias / João Pedro Bernardes / Celso Candeias / Cristina Tété Garcia

1413 No Largo das Mouras Velhas em Faro (2017): novas evidências da necrópole norte de Ossonoba e da sua ocupação medieval Ricardo Costeira da Silva / Paulo Botelho / Fernando Santos / Liliana Nunes

1429 Instrumentos de pesca recuperados numa fábrica de salga em Ossonoba (Faro) Inês Rasteiro / Ricardo Costeira da Silva / Paulo Botelho

1439 A Necrópole Romana do Eirô, Duas Igrejas (Penafiel): intervenção arqueológica de 2016 Laura Sousa / Teresa Soeiro

1457 Ritual, descarte ou afetividade? A presença de Canis lupus familiaris na Necrópole Noroeste de Olisipo (Lisboa)

Beatriz Calapez Santos / Sofia Simões Pereira / Rodrigo Banha da Silva / Sílvia Casimiro / Cleia Detry / Francisca Alves Cardoso

1467 Dinâmicas económicas em Bracara na Antiguidade Tardia Diego Machado / Manuela Martins / Fernanda Magalhães / Natália Botica

1479 Cerâmicas e Vidros da Antiguidade Tardia do Edifício sob a Igreja do Bom Jesus (Vila Nova de Gaia) Joaquim Filipe Ramos

1493 Novos contributos para a topografia histórica de Mértola no período romano e na Antiguidade Tardia Virgílio Lopes

\section{8. Época Medieval}

1511 Cerâmicas islâmicas no Garb setentrional "português": algumas evidências e incógnitas Constança dos Santos / Helena Catarino / Susana Gómez / Maria José Gonçalves / Isabel Inácio / Gonçalo Lopes / Jacinta Bugalhão / Sandra Cavaco / Jaquelina Covaneiro / Isabel Cristina Fernandes / Ana Sofia Gomes 
1525 Contributo para o conhecimento da cosmética islâmica, em Silves, durante a Idade Média Rosa Varela Gomes

1537 Yábura e o seu território - uma análise histórico-arqueológica de Évora entre os séculos VIII-XII José Rui Santos

1547 A encosta sul do Castelo de Palmela - resultados preliminares da escavação arqueológica Luís Filipe Pereira / Michelle Teixeira Santos

1559 A igreja de São Lourenço (Mouraria, Lisboa): um conjunto de silos e de cerâmica medieval islâmica

Andreia Filipa Moreira Rodrigues

1571 O registo material de movimentações populacionais no Médio Tejo, durante os séculos XII-XIII. Dois casos de "sunken featured buildings", nos concelhos de Cartaxo e Torres Novas Marco Liberato / Helena Santos / Nuno Santos

1585 O nordeste transmontano nos alvores da Idade média. Notas para reflexão Ana Maria da Costa Oliveira

1601 Sepulturas escavadas na rocha do Norte de Portugal e do Vale do Douro: primeiros resultados do Projecto SER-NPVD

Mário Jorge Barroca / César Guedes / Andreia Arezes / Ana Maria Oliveira

1619 "Portucalem Castrum Novum" entre o Mediterrâneo e o Atlântico: o estudo dos materiais cerâmicos alto-medievais do arqueossítio da rua de D. Hugo, nํ. 5 (Porto) João Luís Veloso

1627 A Alta Idade Média na fronteira de Lafões: notas preliminares sobre a Arqueologia no Concelho de Vouzela

Manuel Luís Real / Catarina Tente

1641 Um conjunto cerâmico medieval fora de portas: um breve testemunho aveirense Susana Temudo

${ }_{1651}$ Os Lóios do Porto: uma perspetiva integrada no panorama funerário da Baixa Idade Média à Época Moderna em meios urbanos em Portugal

Ana Lema Seabra

1659 O Caminho Português Interior de Santiago como eixo viário na Idade Média Pedro Azevedo

1665 Morfologia Urbana: Um exercício em torno do Castelo de Ourém André Donas-Botto / Jaqueline Pereira

1677 Intervenção arqueológica na Rua Marquês de Pombal/Largo do Espírito Santo (Bucelas, Loures)

Florbela Estêvão / Nathalie Antunes-Ferreira / Dário Ramos Neves / Inês Lisboa

1691 O Cemitério Medieval do Poço do Borratém e a espacialidade funerária na cidade de Lisboa Inês Belém / Vanessa Filipe / Vasco Noronha Vieira / Sónia Ferro / Rodrigo Banha da Silva

1705 Um Espaço Funerário Conventual do séc. XV em Lisboa: o caso do Convento de São Domingos da Cidade Sérgio Pedroso / Sílvia Casimiro / Rodrigo Banha da Silva / Francisca Alves Cardoso

\section{9. Época Moderna e Contemporânea}

1721 Arqueologia Moderna em Portugal: algumas reflexões críticas em torno da quantificação de conjuntos cerâmicos e suas inferências históricas e antropológicas Rodrigo Banha da Silva / André Bargão / Sara da Cruz Ferreira

1733 Faianças de dois contextos entre os finais do século XVI e XVIII do Palácio dos Condes de Penafiel, Lisboa

Martim Lopes / Tomás Mesquita 
1747 Um perfil de consumo do século XVIII na foz do Tejo: O caso do Mercado da Ribeira, Lisboa Sara da Cruz Ferreira / Rodrigo Banha da Silva / André Bargão

1761 Os Cachimbos dos Séculos XVII e XVIII do Palácio Mesquitela e Convento dos Inglesinhos (Lisboa)

Inês Simão / Marina Pinto / João Pimenta / Sara da Cruz Ferreira / André Bargão / Rodrigo Banha da Silva

1775 "Tomar os fumos da erua que chamão em Portugal erua sancta». Estudo de Cachimbos provenientes da Rua do Terreiro do Trigo, Lisboa

Miguel Martins de Sousa / José Pedro Henriques / Vanessa Galiza Filipe

1787 Cachimbos de Barro Caulínitico da Sé da Cidade Velha (República de Cabo Verde)

Rodrigo Banha da Silva / João Pimenta / Clementino Amaro

1801 Algumas considerações sobre espólio não cerâmico recuperado no Largo de Jesus (Lisboa) Carlos Boavida

1815 Adereços de vidro, dos séculos XVI-XVIII, procedentes do antigo Convento de Santana de Lisboa (anéis, braceletes e contas)

Joana Gonçalves / Rosa Varela Gomes / Mário Varela Gomes

1837 Da ostentação, luxo e poder à simplicidade do uso quotidiano: arqueologia e simbologia de joias e adornos da Idade Moderna Portuguesa Jéssica Iglésias

1849 Os amuletos em Portugal - dos objetos às superstições: o coral vermelho Alexandra Vieira

1865 Cerâmicas de Vila Franca de Xira nos séculos XV e XVI Eva Pires

1879 «Não passa por teu o que me pertence». Marcas de individualização associadas a faianças do Convento de Nossa Senhora de Aracoeli, Alcácer do Sal Catarina Parreira / Íris Fragoso / Miguel Martins de Sousa

1891 Cerâmica de Leiria: alguns focos de produção

Jaqueline Pereira / André Donas-Botto

1901 Os Fornos na Rua da Biquinha, em Óbidos Hugo Silva / Filipe Oliveira

1909 A casa de Pêro Fernandes, contador dos contos de D. Manuel I: o sítio arqueológico da Silha do Alferes, Seixal (século XVI) Mariana Nunes Ferreira

1921 O Alto da Vigia (Sintra) e a vigilância e defesa da costa Alexandre Gonçalves / Sandra Santos

1937 O contexto da torre sineira da Igreja de Santa Maria de Loures Paulo Calaveira / Martim Lopes

1949 A Necrópole do Hospital Militar do Castelo de São Jorge e as práticas funerárias na Lisboa de Época Moderna Susana Henriques / Liliana Matias de Carvalho / Ana Amarante / Sofia N. Wasterlain

1963 SAND - Sarilhos Grandes Entre dois Mundos: o adro da Igreja e a Paleobiologia dos ossos humanos recuperados

Paula Alves Pereira / Roger Lee Jesus / Bruno M. Magalhães

1975 Expansão urbana da vila de Cascais no século XVII e XVIII: a intervenção arqueológica na Rua da Vitória no 15 a 17

Tiago Pereira / Vanessa Filipe

1987 Novos dados para o conhecimento do Urbanismo de Faro em época Moderna Ana Rosa 
1995 Um exemplo de Arqueologia Urbana em Alcoutim: o Antigo Edifício dos CTT Marco Fernandes / Marta Dias / Alexandra Gradim / Virgílio Lopes / Susana Gómez Martínez

2007 Palácio dos Ferrazes (Rua das Flores/Rua da Vitória, Porto): a cocheira de Domingos Oliveira Maia

Francisco Raimundo

2021 As muitas vidas de um edifício urbano: História, Arqueologia e Antropologia no antigo Recreatório Paroquial de Penafiel Helena Bernardo / Jorge Sampaio / Marta Borges

2035 O convento de Nossa Senhora da Esperança de Ponta Delgada: o contributo da arqueologia para o conhecimento de um monumento identitário João Gonçalves Araújo / N’Zinga Oliveira

2047 Arqueologia na ilha do Corvo... em busca da capela de Nossa Senhora do Rosário Tânia Manuel Casimiro / José Luís Neto / Luís Borges / Pedro Parreira

2059 Perdidos à vista da Costa. Trabalhos arqueológicos subaquáticos na Barra do Tejo Jorge Freire / José Bettencourt / Augusto Salgado

2071 Arqueologia marítima em Cabo Verde: enquadramento e primeiros resultados do projecto CONCHA

José Bettencourt / Adilson Dias / Carlos Lima / Christelle Chouzenoux / Cristóvão Fonseca / Dúnia Pereira / Gonçalo Lopes / Inês Coelho / Jaylson Monteiro / José Lima / Maria Eugénia Alves / Patrícia Carvalho / Tiago Silva

2085 Trabalhos arqueológicos na Cidade Velha (Ribeira Grande de Santiago, Cabo Verde): reflexões sobre um projecto de investigação e divulgação patrimonial André Teixeira / Jaylson Monteiro / Mariana Mateus / Nireide Tavares / Cristovão Fonseca / Gonçalo C. Lopes / Joana Bento Torres / Dúnia Pereira / André Bargão / Aurélie Mayer / Bruno Zélie / Carlos Lima / Christelle Chouzenoux / Inês Henriques / Inês Pinto Coelho / José Lima / Patrícia Carvalho / Tiago Silva

2103 A antiga fortificação de Quelba / Khor Kalba (E.A.U.). Resultados de quatro campanhas de escavações, problemáticas e perspectivas futuras Rui Carita / Rosa Varela Gomes / Mário Varela Gomes / Kamyar Kamyad

2123 Colónias para homens novos: arqueologia da colonização agrária fascista no noroeste ibérico Xurxo Ayán Vila / José Mạ . Señorán Martín 


\title{
CULTIVOS DE ÉPOCA ROMANA NO BAIXO SABOR: CONTINUIDADE EM TEMPOS DE MUDANÇA?
}

\author{
João Pedro Tereso ${ }^{1}$, Sérgio Simões Pereira ${ }^{2}$, Filipe Santos ${ }^{3}$, Luís Seabra ${ }^{4}$, Filipe Vaz ${ }^{5}$
}

\begin{abstract}
RESUMO
Na sequência de intervenções em oito jazidas romanas no Baixo Sabor foram efetuados estudos carpológicos que permitiram obter informações acerca dos cultivos consumidos e da forma como seriam armazenados. O trigo de grão nu terá sido o principal cultivo em época romana, mas a cevada e o milho-miúdo também terão sido importantes. A presença de uvas está documentada, enquanto leguminosas domésticas e plantas silvestres edíveis são raras.

Este cenário contrasta com outras regiões do Noroeste Peninsular onde, tanto em época romana como na Idade do Ferro, os trigos de grão vestido detinham especial relevância. Com os dados atuais, é difícil entender a peculiaridade do vale do Sabor a este nível, mas alguns fatores ambientais e culturais são aqui adiantados.

Palavras-chave: Agricultura, Romanização, Trás-os-Montes, Arqueobotânica.
\end{abstract}

\begin{abstract}
During the excavation of eight roman sites in the Lower Sabor valley, sediment samples were recovered and carpological analyses were carried out in order to obtain data regarding agriculture and storage.

Naked wheat was the most frequent crop during the Roman period, but barley and millet were also relevant. The presence of grapes is documented while pulses and other wild edible plants were scarce. These results contrast with those found in other regions of Northwest Iberia, both in Roman Times and the Iron Age, where hulled wheats were particularly relevant. Current available data does not allow us to know the reason behind the specificities of the Sabor valley's sites, although some environmental and cultural aspects may provide suitable explanations.
\end{abstract}

Keywords: Agriculture, Romanization, NE Portugal, Archaeobotany.

\section{INTRODUÇÃO}

O conhecimento que temos acerca da agricultura de Época Romana na Península Ibérica advém de uma combinação de dados arqueológicos de diferentes naturezas. Entre estes, os estudos arqueobotânicos assumem particular relevância. Apesar de os dados existentes permitirem já efetuar algumas sínteses (Tereso, Ramil-Rego \& Almeida-da-Silva, 2013; Peña-Chocarro \& alii, 2019) é evidente a escassez de estudos carpológicos em algumas regiões. No Norte de Portugal foram realizados estudos em diversas

\footnotetext{
1. InBIO (Rede de Investigação em Biodiversidade e Biologia Evolutiva, Lab. Associado /CIBIO (Centro de Investigação em Biodiversidade e Recursos Genéticos, Univ.do Porto); UNIARQ - Centro de Arqueologia da Universidade de Lisboa; MHNC-UP - Museu de História Natural e da Ciência da Universidade do Porto; jptereso@gmail.com

2. Arqueólogo Independente; sergiomspereira71@gmail.com

3. Arqueólogo Independente; santos.philipe@gmail.com

4. InBIO (Rede de Investigação em Biodiversidade e Biologia Evolutiva, Lab. Associado /CIBIO (Centro de Investigação em Biodiversidade e Recursos Genéticos, Univ.do Porto); lc_pacos@hotmail.com
}

5. InBIO (Rede de Investigação em Biodiversidade e Biologia Evolutiva, Lab. Associado /CIBIO (Centro de Investigação em Biodiversidade e Recursos Genéticos, Univ.do Porto); filipe.mcvaz@gmail.com 
jazidas, mas, até recentemente, eram quase inexistentes os estudos deste período no nordeste transmontano, sendo as análises da Terronha de Pinhovelo (Tereso, 2009) uma exceção.

Este cenário alterou-se recentemente, quando, entre os anos 2011 e 2014 diversos sítios de cronologia romana foram escavados no Baixo Sabor, incluindo pequenas quintas, casais agrícolas, assim como locais de maior dimensão com evidências estruturais perenes. Estes trabalhos decorreram da minimização dos impactes da implementação do Aproveitamento Hidroelétrico do Baixo Sabor, no âmbito da qual foi estruturado um Plano de Salvaguarda Patrimonial. Este previa a realização de estudos arqueobotânicos, para os quais foram efetuadas amplas recolhas de amostras sedimentares, obtendo-se um vasto corpo de dados que tem vindo a ser publicado. O estudo destas jazidas, concentradas numa área geográfica circunscrita, constitui uma oportunidade para obter dados sem paralelos na região, sobre a diversidade de povoamento e de estratégias económicas, assim como do impacte paisagístico, entre outros, da romanização no nordeste português.

Neste trabalho apresenta-se a síntese dos resultados das análises carpológicas realizadas em jazidas de cronologia romana, com especial enfoque naquelas que permaneciam inéditas. Pretende-se não só identificar os principais cultivos consumidos no vale neste período e tentar obter informações acerca dos seus modos de produção e armazenamento, mas também interpretar estes dados à luz das dinâmicas de povoamento do vale. Embora abordagens socioeconómicas à agricultura e povoamento romano no nordeste trasmontano tenham já sido ensaiadas em estudos anteriores (Lemos, 1993), nunca tiveram em conta dados arqueobotânicos, até recentemente inexistentes para a região. Esta situação é, na verdade, comum a quase todo o ocidente peninsular no que respeita ao período romano, pelo que este estudo assume particular importância.

\section{METODOLOGIA}

Este estudo incide sobre oito sítios arqueológicos (Figura 1), com cronologias entre a viragem da Era e o século $\mathrm{V}$ d.C., intervencionados no Baixo Sabor. Dada a diversidade tipológica das jazidas, verificam-se grandes discrepâncias na dimensão das áreas de intervenção e, consequentemente, no nível de compreensão das dinâmicas de ocupação de cada uma (vide infra). De igual modo, as amostragens com vista aos estudos de arqueobotânica seguiram estratégias distintas em cada sítio, o que se traduz em grandes diferenças entre jazidas, no que se refere ao número de amostras e contextos analisados.

As amostras de sedimento foram flutuadas manualmente com recurso a malhas de $0,5 \mathrm{~mm}$. As flutuações decorreram nos estaleiros do Baixo Sabor ACE e foram da responsabilidade da equipa de escavação. As análises laboratoriais foram realizadas na Faculdade de Ciências da Universidade do Porto.

A fração leve das amostras foi triada com recurso a uma lupa binocular e os frutos e sementes foram identificados por comparação com material atual das coleções de referência do CIBIO e do Herbário da Universidade do Porto e com o auxílio de atlas morfológicos (e.g. Berggren, 1981).

Os resultados podem ser consultados nas tabelas $1 \mathrm{e}$ 2. No texto, os sítios são apresentados seguindo uma ordem geográfica, de Norte para Sul. Alguns contextos estruturais encontravam-se representados por diversas u.e. mas quando estas apresentaram escassos vestígios e cuja diferenciação estratigráfica não foi considerada relevante, os dados foram apresentados ao nível do contexto e não da u.e., de forma a ajustar a dimensão das tabelas a esta publicação.

\section{SÍTIOS ANALISADOS: CARACTERIZA- ÇÃO, AMOSTRAGEM E RESULTADOS}

\subsection{Cabeço da Grincha (Mogadouro)}

O Cabeço da Grincha é uma jazida de cronologia romana com um edifício de pequena dimensão implantado na segunda metade do séc. I d.C., posteriormente remodelado, equipado com um lagar e interpretado como um casal agrícola, que controlaria uma área de passagem do rio Sabor (Pereira \& alii, 2014).

Foram recolhidas 35 amostras em 19 u.e. da segunda fase de ocupação, em especial em depósitos relacionados com o abandono e destruição das estruturas. O único vestígio carpológico identificável é um grão de centeio (Secale cereale), encontrado no derrube da cúpula (u.e. 1078) de um pequeno forno doméstico.

\subsection{Foz da Ribeira do Poio (Mogadouro)}

Localizado junto de um afluente da margem esquerda do rio Sabor, o sítio da Foz da Ribeira do Poio compreende um edifício de $16 \mathrm{~m}$ por $15,3 \mathrm{~m}$, com 12 divisões internas, correspondendo a uma quinta ou 
casal, eventualmente integrado numa unidade fundiária mais abrangente. A jazida parece ter tido, pelo menos, duas fases de ocupação: a implantação de um lagar ou torcularium, durante um período curto entre finais do séc. I d.C. e II d. C (Pereira \& alii, 2014) e, mais tarde, um momento de remodelação em que foi desmontada a unidade de transformação. Após o desmonte dos tanques ou laci, foram criados novos compartimentos e o edifício adaptado a um espaço habitacional, talvez sazonal, ou com outra função não determinada.

As análises antracológicas e carpológicas foram já publicadas (Tereso \& alii, 2018b), pelo que na Tabela 2 é apresentado um somatório dos dados.

Foram recolhidas 63 amostras, num total de $126,7 \mathrm{~L}$ de sedimento, de 36 u.e., principalmente em níveis de abandono e derrubes de telhados. Os frutos e sementes advêm de 19 u.e., uma do exterior do edifício, de um depósito natural (u.e. 1067) anterior à implantação da construção e as restantes de sete compartimentos, integrando: níveis de abandono, sobre pisos de circulação (u.e. 1011, 1028, 1044, 1117), derrubes (1052, 1056, 1058, 1061, 1062, 1089, 1112), depósitos de cobertura de derrubes ou depósitos dispersos sem conexão direta com níveis de ocupação (1004, 1008, 1003), enchimentos de tanques (1097, 1065, 1106) e a vala de fundação de um muro (1038).

Os cereais são raros, contando-se um grão de cevada de grão vestido (Hordeum vulgare subsp. vulgare) e um grão identificado ao nível da tribo (Triticeae). Foram recuperadas, porém, 7 grainhas de uva inteiras (Vitis vinifera), além de alguns fragmentos, assim como um fragmento de caroço de azeitona (Olea europaea). Acrescentam-se ainda escassas sementes de espécies ruderais/daninhas.

\subsection{Vale da Bouça (Mogadouro)}

A intervenção permitiu identificar um edifício relacionado com a produção de vinho ou azeite, ocupado entre o final do séc. II d.C. e o séc. V d.C., segundo a análise de fragmentos de TSH e TSHT. Foram identificadas duas plataformas de prensagem e dois tanques, assim como uma possível cella vinaria pertencentes a um lagar (Pereira \& alii, 2014).

Foram analisadas 10 amostras de 8 u.e., num total de 28,6 L de sedimento, associadas ao abandono de 2 tanques, uma estrutura negativa e dois níveis de circulação. As únicas que forneceram vestígios carpológicos provêm da u.e. 1023, no interior do tanque 1, onde foram encontrados fragmentos de recipientes de armazenagem, selados por um nível de derrube de telha. Neste contexto foi encontrado um grão de Triticeae, assim como nove aquénios de silva/framboesa (Rubus sp.).

\subsection{Chã (Alfândega da Fé)}

Sítio localizado junto à Ribeira de Zacarias, afluente do rio Sabor, com ocupações da Idade do Ferro e de Época Romana. A ocupação do final da Idade do Ferro (séc. IV-I. a.C.) caracterizava-se pela presença de estruturas negativas. Em época romana (séc. I-II d.C.), as estruturas anteriores terão sido colmatadas, implementando-se um pequeno edifício, que embora se encontrasse muito destruído aquando da escavação, deveria pertencer a um pequeno casal rural. Um conjunto de aterros modelou o espaço para a ocupação alto-imperial, sobre a qual ainda se construiu uma estrutura mais grosseira, num momento mais tardio.

Os estudos arqueobotânicos incidiram sobre 43 amostras de 18 u.e. correspondendo principalmente $a$ aterros e enchimentos de fossas. Foram encontradas sementes/frutos identificáveis em três depósitos da fase romana: o enchimento de uma fossa (u.e. 821), o enchimento de um muro (u.e. 813) e um depósito relacionado com o abandono do local (u.e. 802). Os resultados dos estudos arqueobotânicos encontram-se já publicados (Vaz \& alii, 2016) pelo que aqui apresenta-se o somatório desta fase (Tabela 2).

Os frutos e sementes são escassos, tendo sido recolhidas cinco grainhas de uva inteiras e cinco fragmentos, assim como escassas ruderais ou daninhas. Ao contrário das amostras do final da Idade do Ferro deste mesmo sítio, não foram identificados cereais ou leguminosas, o que, considerando o pequeno número de contextos analisados, não deve ser sobrevalorizado.

\subsection{Quinta de Crestelos (Mogadouro)}

Sítio com grande diacronia de ocupação, desde a Pré-história recente até à atualidade, implementado junto à margem esquerda do rio Sabor. Amplamente escavado (10.80o $\left.\mathrm{m}^{2}\right)$, apresenta uma plataforma aplanada e uma crista sobrelevada e alongada, com áreas de declive acentuado entre ambas e uma grande escarpa em direção ao rio. Terá sido um importante povoado durante a $2^{\underline{a}}$ Idade do Ferro, tendo sido definidas diversas cabanas, fossos e muralhas/taludes (Pereira \& alii, 2014). Entre o final da Idade do Ferro e o período alto-imperial (séc. II a.C. a II d.C.), a 
crista terá sido usada principalmente como área de armazenagem, identificando-se aí diversos horrea, tanto circulares como retangulares. Estes apresentavam uma base pétrea, constituída por muretes paralelos, de xisto, um tabulatum em xisto, com paredes de materiais perecíveis revestidos com argila.

Na plataforma inferior, no séc. I d.C. foi construído um grande edifício que terá funcionado como lagar e armazém. Este contava com uma cave rebaixada, um grande horreum e ainda outros compartimentos anexos de funcionalidade indeterminada.

Durante a Antiguidade Tardia verifica-se uma retração da área ocupada, surgem novas construções, ao mesmo tempo que as estruturas anteriores são adaptadas. Ainda que o sítio mantenha a sua função agrícola, o povoado transforma-se numa quinta.

Foram já publicados estudos arqueobotânicos focando os níveis da Idade do Bronze (Martín-Seijo \& alii, 2017), um amplo conjunto de fornos da Idade do Ferro (Vaz \& alii, 2017), os horrea e contextos envolventes do topo da crista (Tereso \& alii, 2018a) (Tabela 2) e os níveis da Antiguidade Tardia e Idade Média (Tereso \& alii, 2018c).

De entre o material já publicado, importa referir, de cronologia romana (séc. I-II d.C), os sedimentos associados a estruturas de armazenagem no topo da crista, nomeadamente os horrea 4, 6, 7 e 8 e o depósito [1348], um nível de escorrência datado por radiocarbono do séc. I ou início de II d.C. e localizado sob os horrea 7 e 8. Para questões cronológicas e para ver os dados pormenorizados das várias u.e. associadas a cada estrutura, conferir Tereso \& alii (2018a). As datações e a estratigrafia do sítio colocam alguns horrea no final da Idade do Ferro, séc. II a I a.C., nomeadamente os horrea 1 e 2. Outros apresentam uma cronologia indeterminada, entre os séc. II a.C e II d.C. Os dados de todos estes contextos encontram-se já publicados (Tereso \& alii, 2018a). Permanecem inéditos e serão aqui apresentados, materiais romanos da plataforma inferior, nomeadamente, o conteúdo de uma fossa, constituída por cinco u.e. (u.e. 1012, 1013, 1018, 1105, 1117), genericamente datadas entre o séc. I a.C. e o séc. I d.C., e um conjunto de três fornos no limite sul da área de escavação, onde foram recolhidos $288 \mathrm{~L}$ de sedimentos, em 19 u.e., algumas delas sem qualquer semente/fruto:

- Um forno de metalurgia (Forno 1), nomeadamente a u.e. 7255 no seu interior.

- Um forno muito destruído aparentemente des- tinado à confeção de alimentos (Forno 2), tendo sido recolhidos macrorrestos nas u.e. $7307 \mathrm{e}$ 7308, no seu interior, e na u.e. 7314 , numa área exterior associada à limpeza da estrutura.

- Um forno de cerâmica (Forno 3), tendo sido recolhidos carporrestos num sedimento no seu interior (u.e. 7335), assim como em níveis de destruição (u.e. 7317, 7328, 7331, 7332), incluindo o depósito [7316], associado à destruição da abóbada.

- Foram ainda recolhidos macrorrestos em dois depósitos (u.e. 7298 e 7304) no interior de uma depressão que se encontrava entre os fornos de cerâmica e de metalurgia.

A Quinta de Crestelos é o sítio romano com o maior conjunto carpológico do Baixo Sabor. Nos sedimentos associados aos horrea alto-imperiais da crista recuperaram-se cerca de 10 mil grãos de cereais, em especial de trigo de grão nu - trigo-mole ou trigo-duro (Triticum aestivum/durum) - e milho-miúdo (Panicum miliaceum). A cevada surge em números muito menores, enquanto os caroços de azeitona (8), as grainhas de uva (5) e as favas (Vicia faba) (3) são ainda mais raros. Sementes e frutos de espécies silvestres não são abundantes, mas são diversos (Tabela 1).

Na plataforma inferior, no interior de uma grande fossa com vários enchimentos e com material da viragem da Era, foram identificados dois grãos de trigo-mole/duro, fragmentos de cereais indeterminados, escassas silvestres - Malva sp. - e aristas de Poaceae, que podem ser domésticas ou silvestres.

Nos níveis associados aos fornos do séc. II d.C., os vestígios carpológicos também não são muito abundantes. No nível de destruição da abóbada do forno de cerâmica foi encontrada a única unidade de centeio (Secale cereale) e na fossa em frente a este forno recuperaram-se dois outros fragmentos de grãos da mesma espécie. De resto, além de três grãos de trigo neste mesmo forno, surgem escassos fragmentos de cereais (Triticeae) em mau estado de preservação nos três fornos. Escassas sementes/frutos de silvestres ruderais ou daninhas foram recolhidos nos três fornos, devendo representar no mínimo 11 espécies diferentes. As Malva sp. são as que surgem num maior número de contextos, seguidas dos Rumex sp. e das gramíneas (Poaceae). O forno de metalurgia é aquele que apresenta maior quantidade de silvestres, devido à presença de 63 sementes de Hyoscyamus niger e 33 mericarpos de Malva nicaeensis. 
A presença de mericarpos possibilitou a identificação das malvas ao nível da espécie, o que torna esta amostra importante pois as sementes de Malva sp. são comuns noutras amostras.

\subsection{Olival da Santa (Alfândega da Fé)}

A escavação neste sítio revelou um edifício complexo, composto por vários compartimentos, incluindo um lagar associado à produção de vinho, cella vinaria e um tanque, assim como cerâmicas de armazenagem. A construção foi alvo de reformulações, associadas a dois momentos sequenciais de ocupação, balizados entre a segunda metade do séc. I d.C. e o período baixo imperial.

Foram analisadas 51 amostras de cronologias que vão desde o Alto Império até à Alta Idade Média. Só em 4 não foi registado o volume de sedimento, as restantes somavam $261 \mathrm{~L}$. Do período aqui analisado, foram recuperados vestígios carpológicos em 18 amostras de 15 u.e.:

- Fase Alto Imperial - um depósito (u.e. 165) associado a diferentes muros; três depósitos associados a níveis de circulação ou ao abandono dos mesmos (102, 103, 109); um nível de abandono (110) sobre os anteriormente mencionados; dois níveis de derrube $(152,1008)$, um piso (1023) e três níveis, sobrepostos entre si, do enchimento de uma fossa de um dolium (do topo para a base: 1041, 1043, 1045).

- Fase Baixo Imperial - dois depósitos associados ao abandono do local $(171,130)$, o preenchimento de uma vala de fundação de um muro desta fase (188) e o enchimento de uma fossa (149).

Foram recuperados 12 grãos de trigo-mole/duro e escassos fragmentos de cereais em mau estado nos níveis das duas fases, enquanto o depósito [165] da fase mais antiga forneceu o único grão de cevada desta jazida. De resto, em u.e. de ambas as fases foram recuperadas escassas sementes/frutos de espécies silvestres.

\subsection{Cemitério dos Mouros (Torre de Moncorvo)}

No Cemitério dos Mouros, na proximidade do sítio do Castelinho, foi identificado um conjunto de estruturas negativas (fossas e buracos de poste) e alinhamentos pétreos possivelmente relacionados com um edifício do séc. I d.C., que terá sido destruído durante as ocupações posteriores do sítio.

Foram estudadas 23 amostras de sedimento, mas só em sete, recolhidas em seis u.e. - num total de 52,5
$\mathrm{L}$ - foram recolhidos vestígios carpológicos. Cinco contextos apresentam uma cronologia Alto-Imperial (séc. I-III d.C.) um outro advém já de níveis dos séc. IV-V d.C. A u.e. 3046 corresponde ao enchimento de uma estrutura em caixa de época alto-imperial, enquanto as restantes cinco são enchimentos de igual número de fossas.

Os vestígios carpológicos são escassos. Foram encontrados raros grãos de trigo e cevada em mau estado de preservação (Tabela 2). As espécies silvestres são igualmente raras e devem corresponder a ervas daninhas.

\subsection{Olival do Poço da Barca (Torre de Moncorvo)} Os contextos arqueológicos verificados neste sítio do séc. I ou II d.C. estavam associados a uma unidade de produção de cerâmica - barreiro, área de preparação, lixeira e o forno. Além do forno, foram encontradas áreas de despejo de peças inutilizadas e detritos resultantes da sua utilização.

Em cinco u.e. foram recolhidas 6 pequenas amostras de sedimento, num total de 9,9 L. Os raros vestígios carpológicos advêm de uma amostra da u.e. 220 (nível de abandono com inclusões esporádicas de cerâmica de cobertura) e outra da u.e. 229 (depósito na base do forno e que se prolonga para o praefurnium). No total, foram encontradas três sementes identificáveis, de espécies silvestres (Tabela 2).

\section{CULTIVOS DE ÉPOCA ROMANA NO BAIXO SABOR: ENQUADRAMENTO REGIONAL}

Os vestígios carpológicos são quase sempre raros nos sítios estudados. A única exceção é a Quinta de Crestelos e, mesmo aí, só nos depósitos dos séc. I-II d.C. associados aos horrea encontramos grande quantidade de frutos e sementes. Aqui o trigo-mole/duro e o milho-miúdo são abundantes, encontrando-se igualmente cevada em diversos contextos. As azeitonas, uvas e favas são muito raras. As três favas deste sítio são as únicas leguminosas identificada em todo o vale, em sítios de época romana.

Nos restantes sítios surgem os mesmos cultivos com exceção da fava - mas em quantidades muito pequenas. Somente no Olival da Santa foram encontradas todas as espécies de cereais encontradas na Quinta de Crestelos o que poderá resultar do maior esforço de amostragem verificado neste sítio. Em alguns sítios, a escassez de dados não deverá ser 
alheia à natureza dos contextos analisados -e.g. no Olival do Poço da Barca só foi escavado um forno cerâmico - ou à pequena quantidade de amostras recolhidas. Ainda assim, a existência de várias quintas ou casais agrícolas fazia esperar uma presença mais visível de frutos/sementes de espécies domésticas. Não foi possível detetar qualquer padrão cronológico claro, dada a raridade dos frutos e sementes e o predomínio de contextos dos dois primeiros séculos após a viragem da Era. A generalidade dos cultivos foi encontrada em jazidas de cronologias anteriores no vale, como os horrea do final da Idade do Ferro do Castelinho (Seabra \& alii, 2020) e da Quinta de Crestelos (Tereso \& alii, 2018a) e as fossas da Idade do Bronze do Terraço das Laranjeiras (Jesus, Tereso \& Gaspar, 2020). O trigo-mole/ duro, o milho-miúdo e a cevada encontram-se no noroeste peninsular desde a Pré-história, mas a presença de centeio, mesmo em contextos romanos é rara. Como vimos, no Baixo Sabor surge em duas jazidas: um grão e dois fragmentos associados aos fornos dos séc. I-II d.C. da Quinta de Crestelos e um grão no derrube da abóbada de um forno do séc. II d.C. no Cabeço da Grincha. Ainda que tenham sido datados grãos de centeio do séc. I a.C. no Crastoeiro (Mondim de Basto) (Seabra \& alii, 2018), este cereal parece ter-se tornado mais frequente na agricultura da região noroeste a partir do Baixo-Império. $\mathrm{Na}$ Quinta de Crestelos, surgem em níveis do séc. V d.C. e posteriores (Tereso \& alii, 2018c), exatamente no mesmo sector dos fornos aqui analisados, pelo que não se pode excluir a existência de perturbações. Só datações de radiocarbono poderão esclarecer a cronologia dos raros grãos descobertos nestes dois sítios, em níveis aparentemente alto-imperiais. As sementes de plantas silvestres, várias delas daninhas de cultivos, são também escassas e não fornecem dados relevantes acerca das estratégias agrícolas. A presença de milho-miúdo atesta a existência de cultivos de Primavera; os restantes cereais, ainda que sendo normalmente cultivos de Inverno, podem ser adaptados a ciclos de vida curtos de Primavera-Verão. Salienta-se a ausência de inflorescências de cereais em quase todos os sítios, o que, juntamente com a escassez de daninhas, pode indicar que os cereais entravam nos locais já processados, o que não é surpreendente considerando o amplo predomínio de trigos de grão nu. Considerando diversos exemplos etnográficos (e.g. Hillman, 1985), o processamento destes produz facilmente grão limpo e poderia ocorrer em eiras afastadas dos locais de habitação. Problemas de amostragem não podem, porém, ser excluídos. Escassos fragmentos de aristas e ráquis foram encontrados na Quinta de Crestelos, mas se isto resulta do maior esforço de amostragem neste sítio ou numa diferença de outro tipo é difícil de avaliar (ver discussão abaixo).

No que respeita às uvas e azeitonas, os vestígios são raros. Foram encontradas grainhas na Foz da Ribeira do Poio (7) e em Chã (5), assim como na Quinta de Crestelos (5). Caroços de azeitona foram recuperados na Quinta de Crestelos (8) e Foz da Ribeira do Poio (1 frag.). Enquanto os vestígios de azeitonas são raros no noroeste peninsular, as grainhas surgem em diversos sítios da Idade do Ferro e Época Romana, sempre em pequenas quantidades (Tereso, 2012; Tereso, Ramil-Rego \& Almeida-da-Silva, 2013), incluindo no sítio do Castelinho (séc. II-I a.C.) (Seabra \& alii, 2020) e Terraço das Laranjeiras (Bronze médio) (Jesus, Tereso \& Gaspar, 2020) no Baixo Sabor. A principal diferença dos resultados obtidos no Baixo Sabor face ao registo arqueobotânico conhecido para o noroeste peninsular encontra-se na ausência de trigos de grão vestido - Triticum aestivum subsp. spelta e Triticum turgidum subsp. dicoccum - comuns em jazidas romanas e da Idade do Ferro de outras áreas, especialmente mais a Oeste (Tereso, 2012; Tereso \& alii, 2013; Seabra \& alii, 2018; Teira-Brión, 2019). Esta ausência havia já sido notada nas jazidas de períodos anteriores, tais como o Castelinho, Quinta de Crestelos e Terraço das Laranjeiras, onde os vestígios carpológicos são abundantes. Neste sentido, as preferências das comunidades que habitaram o Baixo Sabor em Época Romana, a nível cerealífero, demonstram, até à introdução do centeio, uma continuidade desde a Idade do Bronze. As razões das diferenças face à área castreja, a Oeste, não são claras. Por um lado, a parte terminal do vale do Sabor insere-se numa área biogeográfica de fácies mediterrânica, enquanto a maior parte da área castreja encontra-se no limite sul da área Eurosiberiana, de clima atlântico e perfil acidentado, particularmente propícia ao cultivo de trigos vestidos, em especial de espelta, adequado para ambientes húmidos de montanha. Os trigos mole e duro preferem solos mais férteis e terrenos soalheiros. Por outro lado, o Baixo Sabor insere-se numa área cultural distinta, território dos Banienses (Lemos, 1993; Garibo Bodí \& Pereira, 2014), onde se verificam influências evidentes da atual Meseta espanhola. Embora haja 
poucos dados carpológicos que sirvam de comparação, em especial nas áreas próximas ao atual território português, os trigos de grão nu parecem ser dominantes nas áreas do médio e alto Douro - território de Vaceus - desde tempos pré-romanos (Delibes de Castro \& alii, 1995).

Deste modo, questões de âmbito ambiental ou cultural de amplo espectro cronológico poderão justificar a ausência de trigos de grão vestido e o predomínio de trigo-mole/duro. Ainda assim, o predomínio de trigo espelta noutros sítios da região tornam a situação complexa, ainda que não inviabilizem as interpretações acima apresentadas: nos níveis do final da Idade do Ferro/ início de Época Romana do Crasto de Palheiros (Murça) (Figueiral, Sanches \& Cardoso, 2017; Leite, Tereso \& Sanches, 2018), c. 40 $\mathrm{km}$ a oeste, no território de um grupo étnico com nome desconhecido (Garibo Bodí \& Pereira, 2014); nos níveis baixo-imperiais da Terronha de Pinhovelo (Macedo de Cavaleiros) (Tereso, 2009), c. $33 \mathrm{~km} \mathrm{a}$ norte, na transição para a Terra Fria Transmontana, em território dos Zoelae. Seja como for, os dados são ainda escassos para estabelecer uma relação entre o espaço de um grupo humano específico e determinadas escolhas a nível agrícola. Na verdade, a hipótese de o registo carpológico do Baixo Sabor traduzir uma situação meramente local, ainda que diacrónica, adaptada aos solos e ambiente do fundo deste vale, não pode ser excluída. Só a realização de estudos arqueobotânicos em sítios coetâneos, nas áreas de planalto limítrofes ao Sabor, no vale da Vilariça e outras áreas, poderá ajudar a esclarecer esta questão.

\section{AGRICULTURA E POVOAMENTO NO BAIXO SABOR EM ÉPOCA ROMANA}

Os sítios de época romana amostrados no Baixo Sabor apresentam diferentes características (vide supra) e diferentes implantações. A parte terminal do vale do Sabor apresenta um perfil tendencialmente declivoso alternado por poucas áreas mais amplas, onde se concentram abundantes vestígios de ocupação humana, com diacronias por vezes alargadas, desde a Pré-história até à atualidade. É aqui que encontramos a Quinta de Crestelos e, noutra destas áreas, o Cemitério dos Mouros e o Olival do Poço da Barca que forneceram poucos dados carpológicos. A Quinta de Crestelos destaca-se pelos horrea dos séc. I-II d.C., que dão continuidade a estruturas semelhantes dos séc. II-I a.C., associados a abun- dantes cereais. Também em Chã e no Cemitério dos Mouros se verificam pré-existências da Idade do Ferro, porém, difíceis de interpretar devido à fraca preservação das suas estruturas. No último caso, admite-se uma relação com o próximo sítio do Castelinho, onde, à semelhança da Quinta de Crestelos, se destacam os abundantes horrea do final da Idade do Ferro, protegidos por uma imponente fortificação (Santos, 2015).

Por outro lado, contamos com um conjunto de pequenos estabelecimentos rurais romanos - quintas ou casais agrícolas - sem pré-existências e sem paralelos conhecidos no povoamento da Idade do Ferro da região. Alguns destes sítios parecem ter sido ocupados por períodos de tempo relativamente curtos, de 100 a 200 anos (Pereira \& alii, 2014), sendo possível até que alguns se tenham sucedido no tempoa Foz da Ribeira do Poio e o Vale da Bouça situam-se em margens opostas, mas próximos um do outro, sendo o primeiro ocupado entre a segunda metade do séc. I d.C. e o séc. II d.C., enquanto o segundo terá sido ocupado a partir do séc. II d.C..

A presença de tanques e/ou lagares, assim como dolia, sugere que a produção de vinho e/ou azeite teria alguma importância nestes sítios. Ao contrário da Quinta de Crestelos, nestas jazidas, os vestígios de cereais são sempre escassos. Em alguns casos, como vimos, não é possível compreender se esta escassez ou ausência se deve a problemas de amostragem ou se nestes sítios a produção de cereais teria pouco ou nenhum peso económico. Isto não equivale a dizer que os cereais não teriam peso na alimentação das pessoas que habitavam os locais. Mas, devemos ter em conta a premissa segundo a qual a presença de cereais (grãos e inflorescências) em depósitos dispersos nos sítios arqueológicos se deve à reutilização, como combustível, de resíduos de processamento pós-colheita (Hillman, 1981; van der Veen, 2007). Neste sentido, onde os cereais não eram processados ou eram processados em menor quantidade, é menos provável encontrar estes resíduos. Este cenário corrobora a interpretação destes pequenos estabelecimentos como locais especializados na produção de azeite e/ou vinho, sendo provavelmente estes os seus principais cultivos. Foram recuperados vestígios carpológicos de uvas e azeitonas em algumas destas jazidas, nomeadamente Foz da Ribeira do Poio e Chã, mas em pequena quantidade. Por outro lado, não podemos excluir a existência de problemas de preservação, i.e., de sobrevivência à combustão, 
no caso das grainhas, podendo conduzir à sua eventual sub-representação. A preservação em época romana e recuperação em escavação só pode ocorrer se estes resíduos tiverem sido submetidos ao fogo na área intervencionada, usualmente áreas residenciais ou com vestígios estruturais visíveis. Se os resíduos fossem descartados ou reutilizados em outros locais (e.g. adubando terrenos agrícolas), a sua recolha em escavação arqueológica seria improvável. Algum comportamento diferencial face a distintos resíduos - de cereais e de uvas - induziria interpretações erradas da nossa parte. Porém, não temos dados que possam avaliar esta possibilidade.

Quando comparamos os dados destes sítios com a Quinta de Crestelos, as diferenças são evidentes. Neste último sítio, os cereais e a sua armazenagem são elementos cruciais, contando o sítio com diversos horrea, alguns de grande dimensão, e abundantes grãos, em especial de trigo-mole/duro e milho-miúdo. Além disto, localiza-se junto a uma das poucas áreas onde o vale apresenta um perfil mais aberto, potenciando maior produção cerealífera e não só. Neste sítio, também foram encontradas estruturas e cerâmicas relacionadas com a produção e armazenagem de vinho ou azeite. Desta forma, a Quinta de Crestelos, pelo menos nos séc. I-II d.C., distinguir-se-ia da generalidade dos sítios por se tratar de um povoado, não uma quinta, e pela sua maior dimensão e complexidade estrutural. Do ponto de vista carpológico, apresenta diversas e abundantes produções agrícolas. Conta com grande capacidade de armazenagem de cereais e não só, traduzindo eventualmente uma maior escala de produção, ou um papel local relacionado com a armazenagem e distribuição ou comercialização dos bens, distinto do das pequenas quintas. Estas últimas poderiam ter uma produção mais especializada no vinho e/ ou azeite, para comércio local, contrabalançada com pequenas produções cerealíferas ou hortícolas para consumo próprio.

Ainda assim, mais uma vez salientamos as limitações de alguns dados. A grande área de escavação da Quinta de Crestelos contrasta com as intervenções mais localizadas de alguns dos pequenos sítios, ainda que estas últimas tenham sido dimensionadas aos vestígios encontrados à superfície. É possível que tenham restado por descobrir outros elementos estruturais nestes casais agrícolas, tal como é possível que nestes últimos se tenha optado por estratégias de armazenagem e processamento de cereais distintas das da Quinta de Crestelos, não potenciando a sua preservação até hoje. Por fim, a perspetiva que temos do povoamento local está condicionada pelo facto de as intervenções terem sido centradas nas áreas a afetar pela construção das barragens, restando por estudar grande parte das áreas acima da cota de inundação.

\section{CONCLUSÕES}

No Baixo Sabor, passamos de um povoamento concentrado, na $2^{\underline{a}}$ Idade do Ferro, para um povoamento disperso em pequenas quintas e casais, em especial na segunda metade do séc. I d.C. Seriam locais interligados entre si e alguns dos sítios pequenos não terão durado mais de dois séculos (Garibo Bodí \& Pereira, 2014; Pereira \& alii, 2014). Neste período, terá existido no Baixo Sabor uma agricultura diversificada, mas com principal incidência na produção de cereais - em especial trigo-mole e/ou trigo-duro e o milho-miúdo - e de vinho e/ou azeite. Embora a produção cerealífera esteja bem atestada no registo carpológico, principalmente da Quinta de Crestelos, o cultivo de oliveiras ou vinha deixou poucas evidências botânicas, restando, porém, tanques e lagares em diversas pequenas quintas ou casais.

Encontramos um padrão diacrónico no vale, desde a Pré-história recente ao Período Romano, nomeadamente o predomínio de trigos de grão nu face aos trigos de grão vestido, muitos abundantes nos sítios do noroeste peninsular, sendo possível que este padrão resulte de especificidades ambientais e/ou culturais. Infelizmente, a escassez de dados nas regiões limítrofes torna difícil um enquadramento mais amplo dos dados arqueobotânicos do Baixo Sabor. Por outro lado, são necessárias outras perspetivas, mais integradoras do registo arqueológico nesta área de estudo, que cruzem os dados carpológicos com a componente artefactual e mesmo com as dinâmicas estruturais dos sítios analisados. Só assim, as dinâmicas locais ao nível agrícola poderão vir a ser melhor compreendidas.

\section{AGRADECIMENTOS}

Filipe Santos coordenou os trabalhos realizados em Cilhades, Sérgio Pereira coordenou nos restantes sítios romanizados, ambos ao serviço do Baixo Sabor, ACE.

João Tereso coordenou os estudos arqueobotânicos, 
suportado inicialmente pela Faculdade de Ciências da Universidade do Porto (FCUP) e depois pela Fundação para a Ciência e Tecnologia. Filipe Vaz e Luís Seabra realizaram parte dos estudos arqueobotânicos, suportados pela FCUP.

Os seguintes investigadores colaboraram no trabalho laboratorial de carpologia: Ana Jesus, Ginevra Coradeschi, Inês Oliveira Martins, Joana Leite (triagem e identificação), Ana Cláudia Oliveira, Ana Paula Senra Portela, Cristiana Maia Alves (triagem). António Carvalho, Joan Garibo e Helder Carvalho foram responsáveis pelas flutuações das amostras recolhidas em sítios romanizados, ao serviço do Baixo Sabor, ACE.

Agradecemos ainda aos arqueólogos que coordenaram as intervenções em cada um dos sítios referidos, nas campanhas/áreas referidas neste texto: Bruno Silva e José Pereira (C. da Grincha); Rosa Mateos e Hugo Gomes (F. Rib. do Poio); Rosa Mateos e Pedro Costa (V. da Bouça); José Pereira (Chã); Susana Cosme, João Nisa, Javier Larrazabal, José Pereira, Rosa Mateos, Israel Espi e César Neves (Q. de Crestelos); Filipe Pinto e Gabriel Pereira (O. da Santa); Sandra dos Santos (C. dos Mouros); José Pereira (O. do P. da Barca).

\section{BIBLIOGRAFIA}

BERGGREN, Greta (1981) - Atlas of seeds and small fruits of Northwest European plant species with morphological descriptions 3-Salicaceae-Cruciferae. Stockholm: Swedish Museum of Natural History.

DELIBES DE CASTRO, Germán; ROMERO CARNICERO, Fernando; ESCUDERO NAVARRO, Zoa; SANZ MÍNGUEZ, Carlos; SAN MIGUEL MATÉ, Luis Carlos; MARISCAL ÁLVAREZ, Blanca; CUBERO CORPAS, Carmen; UZQUIANO OLLERO, Paloma; MORALES MUÑIZ, Arturo; LIESAU VON LETTOW-VORBECK, Corina, CALONGE CANO, GUILLERMO (1995) - El medio ambiente durante el primer milenio a.C. en el valle medio del Duero. Consideraciones finales. In DELIBES DE CASTRO, Germán; ROMERO CARNICERO, Fernando; MORALES MUNIIZ, Arturo, eds. - Arqueología y Medio ambiente: el primer milenio a. C. en el Duero medio. Valladolid: Junta de Castilla y León, Consejería de Cultura y Turismo, pp. 543-582.

FIGUEIRAL, Isabel; SANCHES, Maria de Jesus; CARDOSO, João (2017) - Crasto de Palheiros (Murça, NE Portugal, $3^{\text {rd }}-1^{\text {st }}$ millennium BC): from archaeological remains to ordinary life. Estudos do Quaternário. Braga. 17, pp. 13-28.

GARIBO BODÍ, Joan; PEREIRA, Sérgio Simões (2014) - A civitas dos banienses: em torno da sua implantação e territorium, In MARTÍNEZ CABALLERO, Santiago; CABAÑERO
MARTÍN, Victor Manuel; MERINO BELLIDO, Carlos, eds. - Arqueologia en el Valle del Duero, del Paleolítico a la Edad Media: Actas de las IV jornadas de jóvenes investigadores del valle del Duero, Segovia, 2O,21 y 22 de noviembre de 2014. Valladolid: Glyphos Publicaciones, pp. 532-557.

HILLMAN, Gordon (1981) - Reconstructing crops husbandry practices from charred remains of crops. In MERCER, Robert, ed. - Farming practice in British Prehistory. Edinburgh: Edinburgh University Press, pp. 123-162.

HILLMAN, Gordon (1985) - Traditional husbandry and processing of archaic cereals in recent times: the operations, products and equipment that might feature in Sumerian texts. Part II: the free-threshing cereals. Bulletin of Sumerian Agriculture. Cambridge. 2, pp. 1-32.

JESUS, Ana; TERESO, João Pedro; GASPAR, Rita (2020) - Interpretative trajectories towards the understanding of negative features using Terraço das Laranjeiras Bronze Age site as a case study. Journal of Archaeological Science: Reports. 30:102222.

LEITE, Margarida Leite; TERESO, João Pedro; SANCHES, Maria de Jesus (2018) - Cultivos da Idade do Ferro no Crasto de Palheiros: novos dados carpológicos da Plataforma Inferior Leste. Cadernos do GEEvH. 7:2, pp. 40-68.

LEMOS, Francisco de Sande (1993) - O Povoamento Romano de Trás-os-Montes Oriental. Braga: Tese de doutoramento apresentada à Universidade do Minho.

MARTÍN-SEIJO, María; TERESO, João Pedro; VAZ, Filipe Costa; GASPAR, Rita; RODRÍGUEZ RELLÁN, Carlos (2017) - Early-Middle Bronze Age communities and wood resources management in northeast Portugal: The Sabor valley. Quaternary International. 458, pp. 28-43.

PEÑA-CHOCARRO, Leonor; PÉREZ-JORDÀ, Guillem; ALONSO, Natàlia; ANTOLÍN, Ferran; TEIRA-BRIÓN, Andrés; TERESO, João Pedro; MONTES MOYA, Eva María; LÓPEZ REYES, Daniel (2019) - Roman and medieval crops in the Iberian Peninsula: A first overview of seeds and fruits from archaeological sites. Quaternary International. 499: Part A, pp. 49-66.

PEREIRA, Sérgio Simões; SILVA, Bruno; LARRAZABAL, Javier; GARIBO, Joan; NISA, João; PEREIRA, José António; MATEOS, Rosa; COSME, Susana (2014) - A romanização no vale do Sabor: de Meirinhos a Remondes (Mogadouro). In DINIS, António Pereira, ed. - I Encontro de Arqueologia de Mogadouro. Mogadouro: Município de Mogadouro, pp. 95-143.

SANTOS, Filipe (2015) - Arquitecturas da II Idade do Ferro. A evolução do sistema defensivo do sítio fortificado do Castelinho (Cilhades, Felgar, Portugal). In RODRÍGUEZ MONTERRUBIO, Óscar; PORTILLA CASADO, Raquel; SASTRE-BLANCO, José; FUENTES MELGAR, Patrícia, eds. - Fortificaciones de la Edad del Hierro: control de los recursos y el territorio. Valladolid: Glyphos Publicaciones, pp. 242-276. 
SEABRA, Luís; SANTOS, Filipe; VAZ, Filipe Costa; LEITE, Joana; TERESO, João Pedro (2020) - Crops behind closed walls: Fortified storage at Castelinho in the Late Iron Age of NW Iberia. Journal of Archaeological Science: Reports. 30:102200.

SEABRA, Luís; TERESO, João Pedro; BETTENCOURT, Ana M.S.; DINIS, António (2018) - Crop diversity and storage structures in the settlement of Crastoeiro (Northwest Iberia): new approaches. Trabajos de Prehistoria. 75:2, pp. 361-378.

TEIRA-BRIÓN, Andrés (2019) - Cambio e resiliencia na agricultura exestión de recursos vexetais no NW da Península Ibérica (10oo a.n.e.-40o d.n.e.). Santiago de Compostela: Tese de doutoramento apresentada à Faculdade de Xeografía e Historia da Universidade de Santiago de Compostela.

TERESO, João Pedro (2009) - Plant macrofossils from the Roman settlement of Terronha de Pinhovelo, northwest Iberia. Vegetation History and Archaeobotany. 18, pp.489-501.

TERESO, João Pedro (2012) - Environmental Change, Agricultural Development and social trends in NW Iberia from the Late Prehistory To The Late Antiquity. Porto: Tese de doutoramento apresentada à Faculdade de Ciências da Universidade do Porto.

TERESO, João Pedro; RAMIL-REGO, Pablo; ALMEIDA-DA-SILVA, Rubim (2013) - Roman agriculture in the conventus Bracaraugustanus (NW Iberia). Journal of Archaeological Science. 4 O, pp. 2848-2858.

TERESO, João Pedro; RAMIL-REGO, Pablo; ÁlVAREZ GONZÁLEZ, Yolanda, LÓPEZ GONZÁlEZ, Luis, ALMEIDA-DA-SILVA, Rubim (2013) - Massive storage in As Laias/O Castelo (Ourense, NW Spain) from the Late Bronze Age/Iron Age transition to the Roman period: a palaeoethnobotanical approach. Journal of Archaeological Science. 40, 3865-3877.

TERESO, João Pedro; VAZ, Filipe Costa; JESUS, Ana; PEREIRA, Sérgio; ESPÍ, Israel; SASTRE-BLANCO, José (2018a) - Os horrea na Quinta de Crestelos (Mogadouro) na Idade do Ferro e Romanização: dados arqueobotânicos sobre armazenagem e construção. Cadernos do GEEvH. 7:2, pp. 95-137.

TERESO, João Pedro; VAZ, Filipe Costa; PEREIRA, Sérgio; MATEOS, Rosa; PEREIRA, José António (2018b) - Recursos vegetais num sítio rural: dados arqueobotânicos no sítio Romano da Foz da Ribeira do Poio (Mogadouro, Nordeste de Portugal). In ROQUE, Ana; MELO, Cristina; AMORIM, Inês; FREITAS, Joana; TORRÃO, Maria, eds. - Alterações Ambientais em Perspetiva Histórica. Porto: CITCEM, pp. 149-179.

TERESO, João Pedro; VAZ, Filipe Costa; SEABRA, Luís; COSME, Susana; PEREIRA, Sérgio Simões (2018c) - Os níveis medievais do sitio de Quinta de Crestelos (Mogadouro): agricultura e paisagem. Arqueologia Medieval. Porto. 14, pp. 75-91.
VAN DER VEEN, Marijke (2007) - Formation processes of desiccated and carbonized plant remains e the identification of routine practice. Journal of Archaeological Science. 34, pp. 968-99o.

VAZ, Filipe Costa, TERESO, João Pedro; MARTÍN-SEIJO, María; PEREIRA, Sérgio Simões; GASPAR, Rita, SEABRA, Luís; SASTRE-BLANCO, José (2017) - Iron Age ovens and hearths from the hilltop of Quinta de Crestelos, Sabor Valley (NE Portugal): An archaeobotanical approach on typology, functionality and firewood use. Quaternary International. 458 , pp. $75-93$.

VAZ, Filipe Costa; TERESO, João Pedro; PEREIRA, José António; PEREIRA, Sérgio Simões (2016) - O potencial interpretativo de contextos secundários e terciários: o caso do estudo arqueobotânico de Chã (Alfândega da Fé). Cadernos do GEEvH. 5:1, pp. 7-28. 


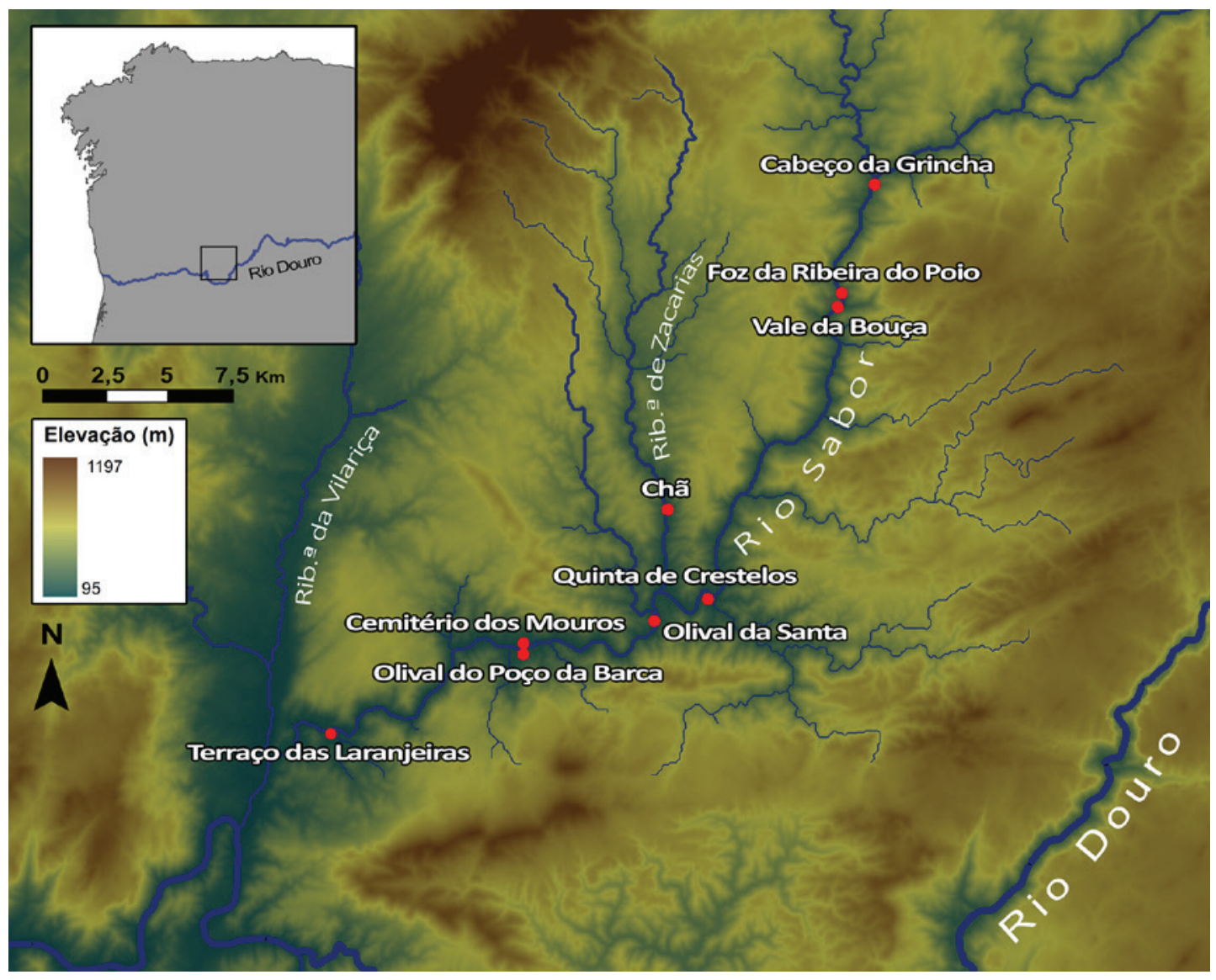

Figura 1 - Localização dos sítios analisados. 


\begin{tabular}{|c|c|c|c|c|c|c|c|c|c|c|c|c|c|c|}
\hline & \multicolumn{8}{|c|}{ Plataforma inferior } & \multirow{2}{*}{\multicolumn{5}{|c|}{$\begin{array}{c}\text { Crista } \\
\text { I - II d.C }\end{array}$}} & \\
\hline & \begin{tabular}{|l|} 
I a.C.- \\
I d.C.
\end{tabular} & \multicolumn{7}{|c|}{ I - II d.C. } & & & & & & \\
\hline & \multirow{2}{*}{$\begin{array}{c}\text { Fossa } \\
\mathbf{1}\end{array}$} & \multirow{2}{*}{$\begin{array}{c}\text { Forno } \\
1\end{array}$} & \multicolumn{2}{|c|}{ Forno 2} & \multicolumn{3}{|c|}{ Forno 3} & \multirow{2}{*}{ Fossa } & \multicolumn{4}{|c|}{ Horrea } & \multirow{2}{*}{ U.E. 1348} & \\
\hline & & & Int. & Ext. & Int. & Abóbada & Aband. & & 4 & 6 & 7 & 8 & & Total \\
\hline \multicolumn{15}{|l|}{ Cereais (grão) } \\
\hline Hordeum vulgare & & & & & & & & & 1 & $/ 1$ & $22 / 9$ & & $33 / 39$ & $56 / 49$ \\
\hline Panicum miliaceum & & & & & & & & & & $2 / 1$ & $10 / 5$ & 5 & $4710 / 2460$ & $4727 / 2466$ \\
\hline Panicoideae & & & & & & & 1 & & & & & 1 & 111 & 113 \\
\hline Secale cereale & & & & & & 1 & & $/ 2$ & & & & & & $1 / 2$ \\
\hline $\begin{array}{l}\text { Triticum aestivum/ } \\
\text { durum }\end{array}$ & 2 & & & & & & $3 / 1$ & & $4 / 3$ & $182 / 29$ & $663 / 135$ & $\begin{array}{l}28 \\
/ 9\end{array}$ & $3843 / 255$ & $4725 / 432$ \\
\hline $\begin{array}{l}\text { T.aestivum/durum } \\
\text { (frag. longitudinal) }\end{array}$ & & & & & & & & & 3 & 87 & 290 & 13 & 513 & 906 \\
\hline Triticum sp. & & & & & & & 1 & 1 & & & & & & 2 \\
\hline Triticeae & & & & & & & $3 / 19$ & $1 / 5$ & $1 / 11$ & $23 / 271$ & $58 / 1121$ & $3 / 28$ & $477 / 1039$ & $566 / 2520$ \\
\hline $\begin{array}{l}\text { Triticeae (escutelo / } \\
\text { embrião) }\end{array}$ & & & & & & & 1 & & & 15 & 36 & & $223 / 4$ & $275 / 4$ \\
\hline \multicolumn{15}{|l|}{ Outros cultivos } \\
\hline \begin{tabular}{|l|}
$\begin{array}{l}\text { Olea europaea } \\
\text { (endocarpo) }\end{array}$ \\
\end{tabular} & & & & & & & & & & $/ 1$ & $8 / 4$ & & & $8 / 5$ \\
\hline Vicia faba (semente) & & & & & & & & & & $2 / 8$ & & & 1 & $3 / 8$ \\
\hline Vitis vinifera (semente) & & & & & & & & & & & 5 & & & 5 \\
\hline \multicolumn{15}{|l|}{ Silvestres } \\
\hline Allium sp. (semente) & & & & & & & & & & & $4 / 2$ & & & $4 / 2$ \\
\hline Asteraceae (aquénio) & & & & & & & & & & & $7 / 4$ & & & $7 / 4$ \\
\hline $\begin{array}{l}\text { Asterolinon linum- } \\
\text { stellatum (semente) }\end{array}$ & & & & & & & & & & 1 & & & & 1 \\
\hline Briófita & & & & & & 1 & & & & & & & & 1 \\
\hline $\begin{array}{l}\text { Caryophyllaceae } \\
\text { (semente) }\end{array}$ & & & & & & & 1 & & & & & & 9 & 10 \\
\hline $\begin{array}{l}\text { Chenopodiaceae } \\
\text { (semente) }\end{array}$ & & & & $/ 3$ & & & & & & & & & & $/ 3$ \\
\hline $\begin{array}{l}\text { Chenopodium } \\
\text { sp.(semente) }\end{array}$ & & 2 & & 1 & 1 & & & & & & & & & 4 \\
\hline Cistus ladanifer (cápsula) & & $/ 2$ & & & & & & & & & $/ 26$ & & & $/ 28$ \\
\hline Fabaceae (semente) & & & & & & & 1 & & 1 & & & & & 2 \\
\hline $\begin{array}{l}\text { Hyoscyamus niger } \\
\text { (semente) }\end{array}$ & & $63 / 46$ & & & & & & & & & & & & $63 / 46$ \\
\hline Lolium/Festuca (grão) & & & & & & & & & & 2 & $3 / 1$ & & $/ 4$ & $5 / 4$ \\
\hline $\begin{array}{l}\text { Malva nicaeensis } \\
\text { (mericarpo) }\end{array}$ & & 33 & & & & & & & & & & & & 33 \\
\hline Malva sp. (semente) & $1 / 1$ & $3 / 6$ & $2 / 1$ & 1 & 2 & $6 / 2$ & $7 / 1$ & & & 1 & $/ 1$ & & & $23 / 12$ \\
\hline $\begin{array}{l}\text { Medicago tipo } \\
\text { polymorpha (semente) }\end{array}$ & & & & & & 1 & & & & & & & & 1 \\
\hline $\begin{array}{l}\text { Ornithopus sp. (seg. } \\
\text { lomento) }\end{array}$ & & & & & & & & & & & 1 & & 1 & 2 \\
\hline Poaceae (frag. caule) & & & & & 1 & & & & & & & & & 1 \\
\hline Poaceae (frag. arista) & 4 & & & & 1 & & 2 & & & 1 & 2 & & & 10 \\
\hline Poaceae (grão) & & 1 & & & & 1 & $5 / 3$ & & & $3 / 1$ & $2 / 3$ & & $30 / 13$ & $42 / 21$ \\
\hline Poaceae (frag. ráquis) & & & & & & & 2 & & & & & & & 2 \\
\hline $\begin{array}{l}\text { Portulaca oleraceae } \\
\text { (semente) }\end{array}$ & & & & & & 1 & & & & & & & & 1 \\
\hline $\begin{array}{l}\text { Potentilla/Fragaria } \\
\text { (aquénio) }\end{array}$ & & & & 1 & & & & & & & & & & 1 \\
\hline Rumexsp. (aquénio) & & & & 1 & & 1 & 2 & & & & & & & 4 \\
\hline $\begin{array}{l}\text { Rumex crispus/ } \\
\text { obtusifolius (aquénio) }\end{array}$ & & & 4 & & & 2 & & & & & & & & 6 \\
\hline $\begin{array}{l}\text { Sherardia arvensis } \\
\text { (mericarpo) }\end{array}$ & & & & & & & & & & & 1 & & & 1 \\
\hline Vicia/Lathyrus (semente) & & 1 & & & & & & & & & 2 & & & 3 \\
\hline Indeterminado & 37 & 149 & 4 & 20 & 3 & 10 & 32 & 36 & 30 & $1 / 1129$ & 4465 & 95 & $17 / 19987$ & $18 / 25997$ \\
\hline
\end{tabular}

Tabela 1 - Quinta de Crestelos: síntese de dados carpológicos (unidades / fragmentos) 


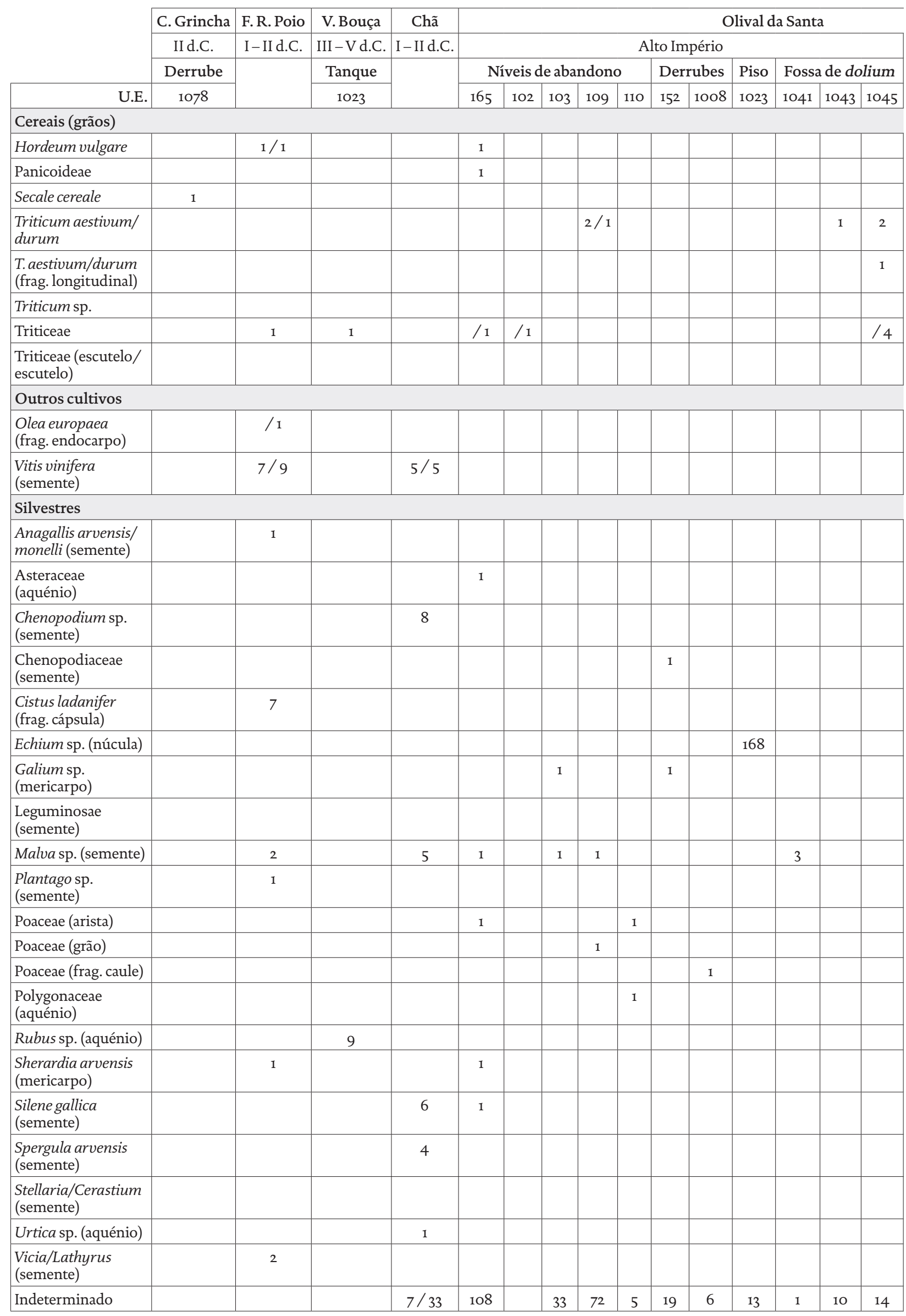

Tabela 2 - Dados carpológicos dos sítios romanos (unidades / fragmentos). 


\begin{tabular}{|c|c|c|c|c|c|c|c|c|c|c|c|c|c|}
\hline \multirow[b]{4}{*}{ U.E. } & \multirow{2}{*}{\multicolumn{4}{|c|}{$\begin{array}{l}\text { Olival da Santa } \\
\text { Baixo Império }\end{array}$}} & \multicolumn{7}{|c|}{ Cemitério dos Mouros } & \multirow{4}{*}{$\begin{array}{c}\text { O.P. Barca } \\
\text { I-II d.C. } \\
\text { Abandono } \\
\end{array}$} & \multirow[b]{4}{*}{ Total } \\
\hline & & & & & \multicolumn{5}{|c|}{ I-III d.C. } & \multirow{2}{*}{\multicolumn{2}{|c|}{ IV-V }} & & \\
\hline & \multicolumn{2}{|c|}{ Abandono } & \multirow{2}{*}{$\begin{array}{l}\text { Vala } \\
188 \\
\end{array}$} & \multirow{2}{*}{\begin{tabular}{|c|} 
Fossa \\
149 \\
\end{tabular}} & \multirow{2}{*}{$\begin{array}{l}\text { Cista } \\
3046 \\
\end{array}$} & \multicolumn{4}{|c|}{ Fossas } & & & & \\
\hline & 130 & 171 & & & & 2043 & 2047 & 4041 & 2034 & 3045 & 3045 & & \\
\hline \multicolumn{14}{|l|}{ Cereais (grãos) } \\
\hline Hordeum vulgare & & & & & & & $/ 1$ & & & & $/ 1$ & & $2 / 3$ \\
\hline Panicoideae & & & & & & & & & & & & & 1 \\
\hline Secale cereale & & & & & & & & & & & & & 1 \\
\hline $\begin{array}{l}\text { Triticum aestivum/ } \\
\text { durum }\end{array}$ & & 1 & 6 & $/ 2$ & & & & & & & & & $12 / 3$ \\
\hline $\begin{array}{l}\text { T. aestivum/durum } \\
\text { (frag. longitudinal) }\end{array}$ & & & & & & & & & & & & & 1 \\
\hline Triticum sp. & & & & & & & & 1 & & & & & 1 \\
\hline Triticeae & & $/ 2$ & $2 / 1$ & $/ 5$ & 1 & & $/ 1$ & $/ 2$ & & & 2 & & $7 / 20$ \\
\hline $\begin{array}{l}\text { Triticeae (escutelo/ } \\
\text { escutelo) }\end{array}$ & & 1 & $/ 1$ & & & & & & & & & & $1 / 1$ \\
\hline \multicolumn{14}{|l|}{ Outros cultivos } \\
\hline $\begin{array}{l}\text { Olea europaea } \\
\text { (frag. endocarpo) }\end{array}$ & & & & & & & & & & & & & 1 \\
\hline $\begin{array}{l}\text { Vitis vinifera } \\
\text { (semente) }\end{array}$ & & & & & & & & & & & & & $12 / 14$ \\
\hline \multicolumn{14}{|l|}{ Silvestres } \\
\hline $\begin{array}{l}\text { Anagallis arvensis/ } \\
\text { monelli (semente) }\end{array}$ & & & & & & & & & & & & & 1 \\
\hline $\begin{array}{l}\begin{array}{l}\text { Asteraceae } \\
\text { (aquénio) }\end{array} \\
\end{array}$ & & & & & & & & & & & & & 1 \\
\hline $\begin{array}{l}\text { Chenopodium sp. } \\
\text { (semente) }\end{array}$ & & & & & & & & & & & & & 8 \\
\hline $\begin{array}{l}\text { Chenopodiaceae } \\
\text { (semente) }\end{array}$ & & & & & & & & & & & & & 1 \\
\hline $\begin{array}{l}\text { Cistus ladanifer } \\
\text { (frag. cápsula) }\end{array}$ & & & & & & & & & & & & & 7 \\
\hline Echium sp. (núcula) & & & & & & & & & & & & & 168 \\
\hline $\begin{array}{l}\text { Galium sp. } \\
\text { (mericarpo) }\end{array}$ & & & & & & & & & & 1 & & & 3 \\
\hline $\begin{array}{l}\text { Leguminosae } \\
\text { (semente) }\end{array}$ & & & & & & & & 1 & 1 & 1 & & & 3 \\
\hline Malva sp. (semente) & & 1 & 1 & 1 & & & & & & & & & 16 \\
\hline $\begin{array}{l}\text { Plantago sp. } \\
\text { (semente) }\end{array}$ & & & & & & & & & & & & & 1 \\
\hline Poaceae (arista) & 4 & & & & & 1 & & & & & & & 7 \\
\hline Poaceae (grão) & & & & & & & & 1 & & & & & 2 \\
\hline Poaceae (frag. caule) & & & & & & & & & & & & & 1 \\
\hline $\begin{array}{l}\text { Polygonaceae } \\
\text { (aquénio) }\end{array}$ & & & & 1 & & & & & & & & & 2 \\
\hline Rubus sp. (aquénio) & & & & & & & & & & & & & 9 \\
\hline $\begin{array}{l}\text { Sherardia arvensis } \\
\text { (mericarpo) }\end{array}$ & & & & & & & & & & & & 1 & 3 \\
\hline $\begin{array}{l}\text { Silene gallica } \\
\text { (semente) }\end{array}$ & & & & & & & & & & & & & 7 \\
\hline $\begin{array}{l}\text { Spergula arvensis } \\
\text { (semente) }\end{array}$ & & & & & & & & & & & & & 4 \\
\hline $\begin{array}{l}\text { Stellaria/Cerastium } \\
\text { (semente) }\end{array}$ & & & & & & & & 1 & & & & & 1 \\
\hline Urtica sp. (aquénio) & & & & & & & & & & & & & 1 \\
\hline $\begin{array}{l}\text { Vicia/Lathyrus } \\
\text { (semente) }\end{array}$ & & & & & & & & & & & & 2 & 4 \\
\hline Indeterminado & 3 & 16 & 34 & 104 & 1 & 1 & & & & & $1 / 2$ & 8 & $8 / 483$ \\
\hline
\end{tabular}

Tabela 2 (continuação) - Dados carpológicos dos sítios romanos (unidades / fragmentos). 



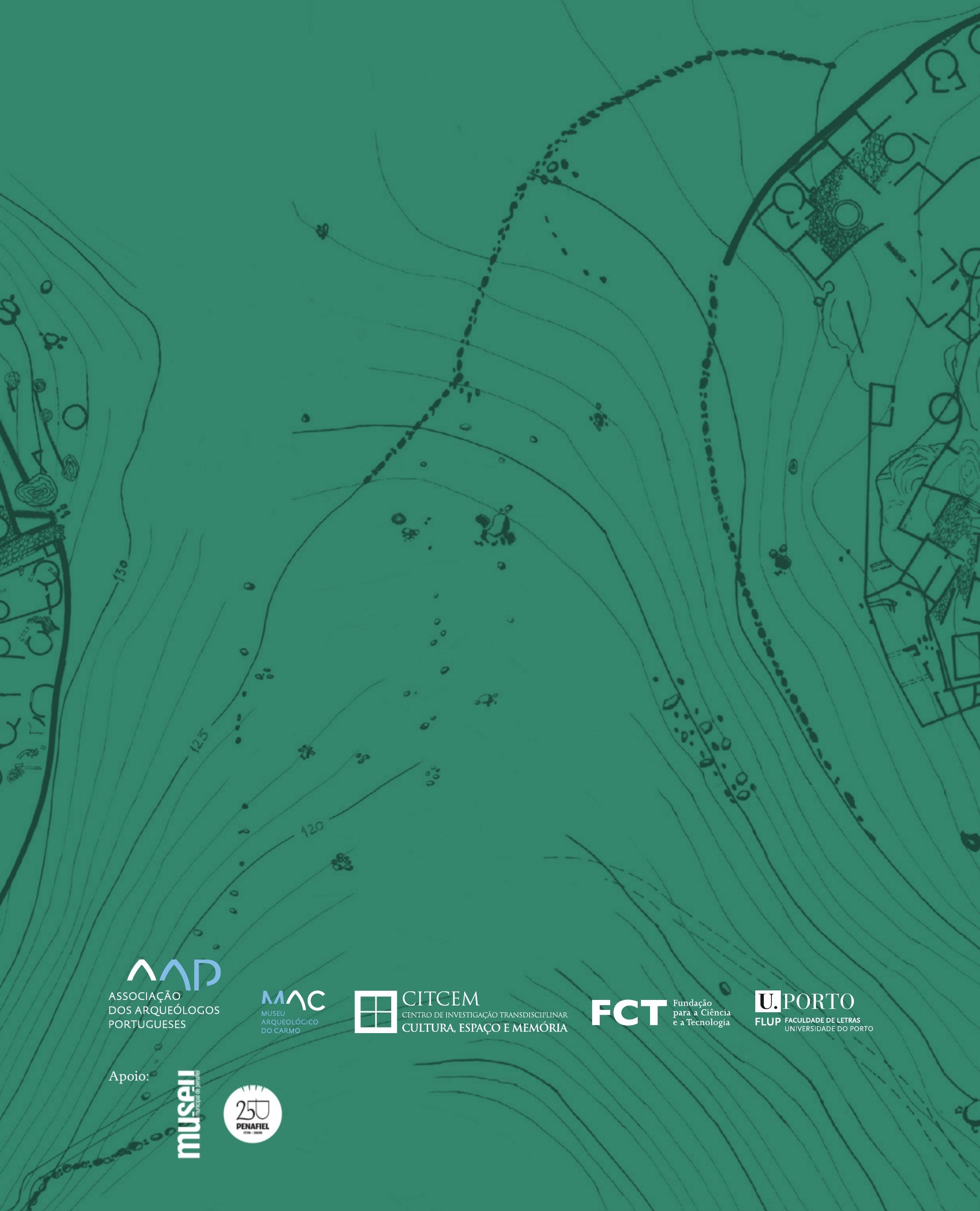

